\title{
Tectonics and seismicity of the Tindari Fault System, southern Italy: Crustal deformations at the transition between ongoing contractional and extensional domains located above the edge of a subducting slab
}

\author{
Andrea Billi, ${ }^{1}$ Graziella Barberi, ${ }^{2}$ Claudio Faccenna, ${ }^{1}$ Giancarlo Neri, ${ }^{3}$ \\ Fabrizio Pepe, ${ }^{4}$ and Attilio Sulli ${ }^{4}$
}

Received 3 November 2004; revised 13 December 2005; accepted 17 January 2006; published 30 March 2006.

[1] The Tindari Fault System (southern Tyrrhenian Sea, Italy) is a regional zone of brittle deformation located at the transition between ongoing contractional and extensional crustal compartments and lying above the western edge of a narrow subducting slab. Onshore structural data, an offshore seismic reflection profile, and earthquake data are analyzed to constrain the present geometry of the Tindari Fault System and its tectonic evolution since Neogene, including the present seismicity. Results show that this zone of deformation consists of a broad NNW trending system of faults including sets of right-lateral, left-lateral, and extensional faults as well as early strike-slip faults reworked under late extension. Earthquakes and other neotectonic data provide evidence that the Tindari Fault System is still active in the central and northern sectors and mostly accommodates extensional or rightlateral transtensional displacements on a diffuse array of faults. From these data, a multiphase tectonic history is inferred, including an early phase as a right-lateral strike-slip fault and a late extensional reworking under the influence of the subductionrelated processes, which have led to the formation of the Tyrrhenian back-arc basin. Within the present, regional, geodynamic context, the Tindari Fault System is interpreted as an ongoing accommodation zone between the adjacent contractional and extensional crustal compartments, these tectonic compartments relating to the complex processes of plate convergence occurring in the region. The Tindari Fault System might also be included in an incipient, oblique-extensional, transfer zone linking the ongoing contractional belts in the Calabrian-Ionian and

\footnotetext{
${ }^{1}$ Dipartimento di Scienze Geologiche, Università "Roma Tre”, Rome, Italy.

${ }^{2}$ Istituto Nazionale di Geofisica e Vulcanologia, Catania, Italy.

${ }^{3}$ Dipartimento di Scienze della Terra, Università di Messina, Messina, Italy. Italy

${ }^{4}$ Dipartimento di Geologia e Geodesia, Università di Palermo, Palermo,

Copyright 2006 by the American Geophysical Union. 0278-7407/06/2004TC001763
}

southern Tyrrhenian compartments. Citation: Billi, A., G. Barberi, C. Faccenna, G. Neri, F. Pepe, and A. Sulli (2006), Tectonics and seismicity of the Tindari Fault System, southern Italy: Crustal deformations at the transition between ongoing contractional and extensional domains located above the edge of a subducting slab, Tectonics, 25, TC2006, doi:10.1029/ $2004 \mathrm{TC} 001763$.

\section{Introduction}

[2] The Neogene-Quaternary tectonics of the central Mediterranean has been controlled by a complex interplay of small plates within the larger frame of convergence between Africa and Eurasia (Figure 1a) [McKenzie, 1970, 1972; Alvarez et al., 1974; Barberi et al., 1974; D'Argenio et al., 1980]. Relative movements of these plates and interactions along their margins have produced contractional (e.g., Alps and Apennines) and extensional (e.g., Tyrrhenian Sea) domains [Laubscher, 1988; Royden and Burchfiel, 1989; Patacca et al., 1990]. It is widely accepted, for instance, that the causes for the extensional strain regime that has led to the appearance of the Tyrrhenian oceanic basin (Figure 1b) are connected with the subduction and rollback of the Ionian plate underneath the Calabria [Malinverno and Ryan, 1986; Kastens et al., 1988]. At present, the occurrence of the subducted Ionian slab beneath the Calabria and the Tyrrhenian Sea is inferred by subcrustal earthquakes (Figure 1b), which define, to the east of the Aeolian Islands, a NW dipping, narrow, Wadati-Benioff zone [Isacks and Molnar, 1971; Anderson and Jackson, 1987; Giardini and Velonà, 1988].

[3] The shallow seismicity ( $<30 \mathrm{~km}$ deep) of the southern Tyrrhenian Sea shows the occurrence of two adjacent compartments, which are characterized by different tectonic regimes: a N-S contraction, to the northwest of the Aeolian Islands, and a NW-SE extension, to the east and southeast of these islands (Figure 2) [Anderson and Jackson, 1987; Neri et al., 2003; Montone et al., 2004; Pondrelli et al., 2004]. The transition zone between these compartments corresponds, at depths of about $100-200 \mathrm{~km}$, to the lateral (western) termination of the Ionian Wadati-Benioff zone [Piromallo and Morelli, 2003; Faccenna et al., 2004, 2005], and, at shallow depths (i.e., $<30 \mathrm{~km}$ ), to the Tindari Fault System and to recent volcanic edifices (i.e., Vulcano, Lipari, and Salina, Figures 1 and 2). 

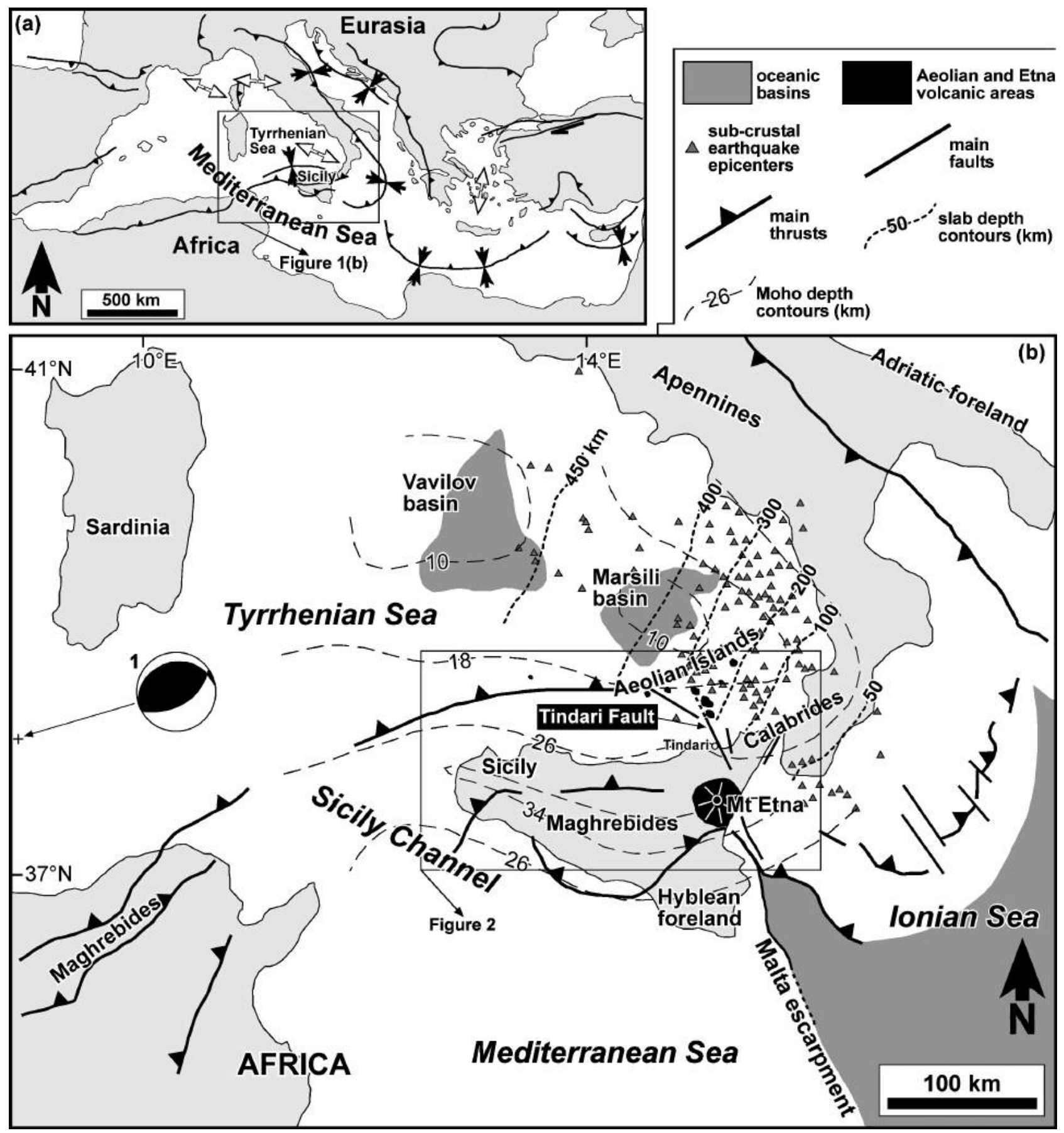

Figure 1. (a) Tectonic map of the Mediterranean region displaying major thrust-fold and strike-slip belts. Arrows indicate ongoing extension and contraction. (b) Tectonic map of Sicily, Tyrrhenian Sea, and adjacent areas. For explanation of the earthquake fault plane solution 1, see the text and Figure 2.

[4] The Tindari Fault System consists of a NNW striking set of faults previously documented in the northeastern Sicily between Mt Etna and the Aeolian Islands [Atzori et al., 1978; Ghisetti, 1979; Ghisetti and Vezzani, 1981; Tortorici et al., 1995b]. Both right-lateral and extensional displacements are documented along the Tindari Fault System [Ghisetti, 1979], but very few is known about the temporal relationship between them and about their spatial distribution along the fault system. Published age constraints allow only to date the fault activity as young as middle-upper Pleistocene in the Tindari area [Ghisetti, 1979; Catalano and Cinque, 1995; Catalano and Di Stefano, 1997], and as young as 50-25 kyr B.P. at Vulcano Island [Voltaggio et al., 1997]; however, this fault system is 


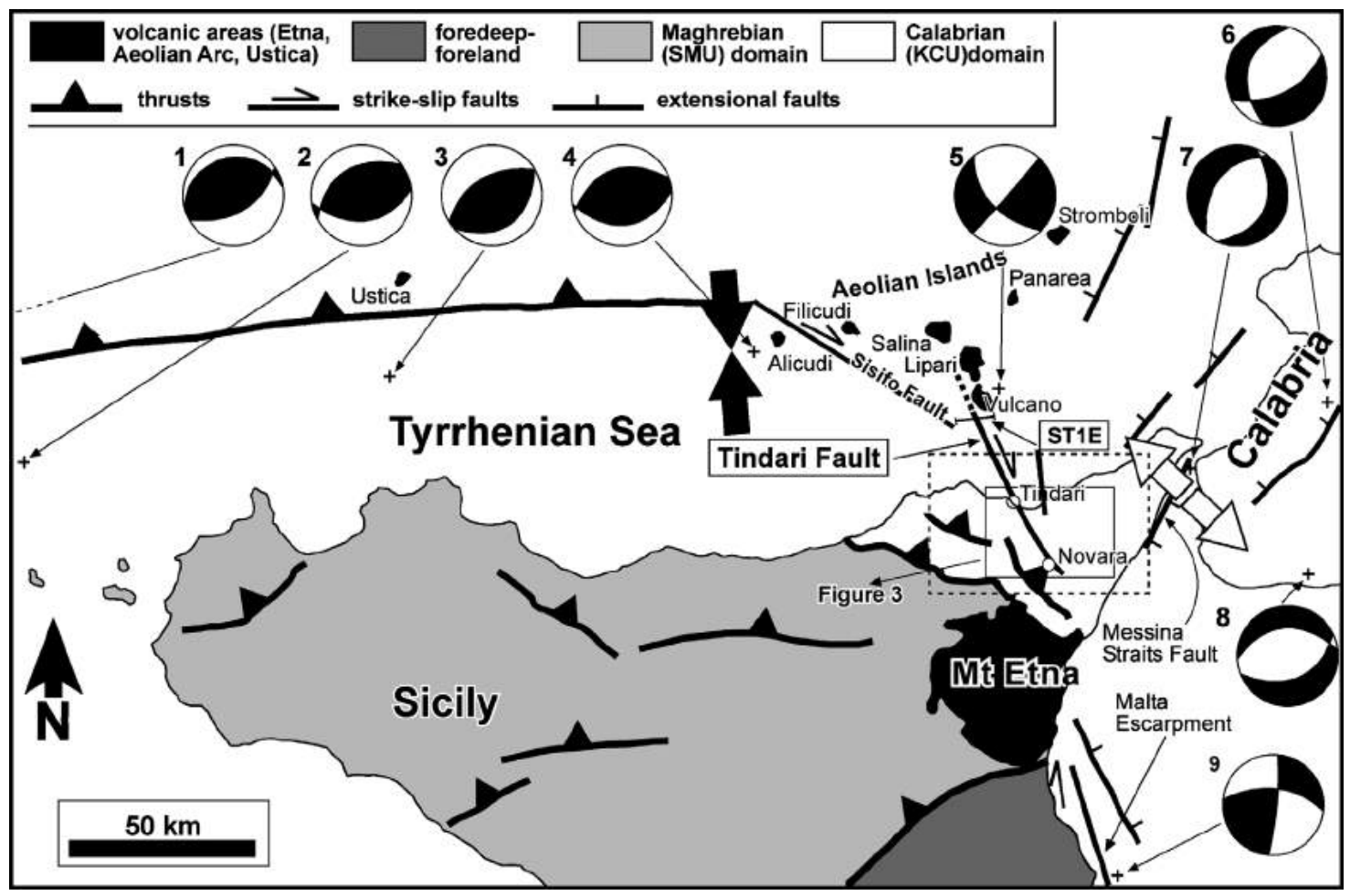

Figure 2. Major tectonic domains of Sicily (i.e., volcanic areas, foredeep-foreland, Sicilian-Maghrebian SMU and Kabilian-Peloritan-Calabrian KCU thrust sheets). The active thrust zone in the southern Tyrrhenian Sea has black triangles (i.e., indicating the thrust hanging wall) on both sides because its major vergence is still uncertain. From the data of Pepe et al. [2005], the vergence of this thrust zone is more likely toward the south. Fault plane solutions and locations of shallow earthquakes $(<30 \mathrm{~km}$ deep) are shown as balls and crosses, respectively. Location of the fault plane solution 1 is shown in Figure $1 \mathrm{~b}$. Fault plane solutions 1, 2, 4, 5, 8, and 9 are from the centroid moment tensor catalog available at http:// www.seismology.harvard.edu [see also Pondrelli et al., 1995]. Fault plane solutions 3 and 6 are from the Istituto Nazionale di Geofisica e Vulcanologia catalog available at http://www.ingv.it. Fault plane solution 7 is from Gasparini et al. [1982] and refers to the Messina Straits great earthquake of 1908 (the strongest event in Italy in the 20th century with a magnitude of about 7-7.5). Black (contraction) and white (extension) arrow pairs show the seismic stress as estimated by Neri et al. [2003]. The rectangular dashed box including the Tindari-Novara area indicates the region studied by stereoscopic aerial photographs.

ongoing seismically active in the northern sector, with earthquakes since 1978 characterized by both extensional and strike-slip fault plane solutions, and by magnitudes $\leq 5.5$ [Neri et al., 1996]. In particular, the offshore region that includes the Tindari Fault System has been the area of the greatest earthquake activity in the last decades along the Calabro-Sicilian portion of the Tyrrhenian margin [Neri et al., 2003]. Recent GPS data have shown that the northeastern block of Sicily is moving toward the north, whereas the southern and western blocks are moving toward the northwest (i.e., velocities relative to fixed Eurasia). The differential movements between the crustal blocks of Sicily may be at the origin of the ongoing tectonic activity along the Tindari Fault System [Hollestein et al., 2003; D'Agostino and Selvaggi, 2004; Goes et al., 2004; Pondrelli et al., 2004].

[5] Despite the important role of the Tindari Fault System in the seismicity, tectonics, and volcanism of the southern Tyrrhenian Sea [e.g., Monaco and Tortorici, 2000; Marani and Trua, 2002; De Astis et al., 2003; Goes et al., 2004; Govers and Wortel, 2005], several issues about the structural architecture (i.e., distribution, attitude, and slip of fault segments) of the Tindari Fault System are poorly constrained, particularly in the area between Tindari and Vulcano Island. Furthermore, the southern termination of the fault has largely been debated and several authors extend the southern tip of the fault to the Ionian coast of Sicily near Mt Etna [e.g., Govers and Wortel, 2005, and references therein] and eventually link the fault with the Malta Escarpment (i.e., across the destructive plate margin between Africa and Eurasia [e.g., Lanzafame and Bousquet, 1997]). Also, the tectonic role of the Tindari Fault System within the seismically heterogeneous continental margin of the northern Sicily and the relationship with the subducting Ionian slab are still poorly understood. 
[6] In this paper, we integrate geological and geophysical data (i.e., structural data, an offshore seismic reflection profile, and earthquake data) to provide new constraints on the present-day geometry and seismicity of the Tindari Fault System, and to reconstruct its tectonic evolution since Neogene. The analysis we present is, furthermore, a contribution toward the correct understanding of the role of this system of faults in the present and recent tectonics of the southern Tyrrhenian Sea and eastern Sicily.

\section{Geological Setting}

[7] In the central Mediterranean region (Figure 1), the Neogene-Quaternary convergence between Africa and Eurasia led to the formation of two main tectonic domains [Caire, 1970; Barberi et al., 1974; Boccaletti and Manetti, 1978; Patacca et al., 1990]: the Apenninic thrust-fold belt and the Tyrrhenian back-arc basin (Figure 2). Different lithosphere thicknesses and Moho depths characterize these domains. The lithosphere thickness is about $70 \mathrm{~km}$ in the Sicily mainland (i.e., Apenninic domain) and reduces to about $30 \mathrm{~km}$ in the central Tyrrhenian Sea where an oceanic lithosphere occurs [Ansorge et al., 1992]. The Moho is about $25-30 \mathrm{~km}$ deep along the northern coast of Sicily (i.e., continental domain) and shallows to $9-12 \mathrm{~km}$ toward the north at the continent-ocean transition (Figure 2) [Nicolich, 1989; Pepe et al., 2000].

[8] In Sicily, the Apenninic thrust-fold belt is constituted by the inner Kabilian-Peloritan-Calabrian (KCU) nappe thrusting on top of the Sicilian-Maghrebian (SMU) thrust sheets [Ogniben, 1960; Caire, 1970; Amodio-Morelli et al., 1976; Catalano and D'Argenio, 1978; Catalano et al., 1996]. The KCU units are exposed in the northeastern Sicily, whereas the SMU ones are exposed in the central and western Sicily (Figure 2). The SMU belt consists of imbricate sheets of Mesozoic-early Tertiary carbonate rocks, whereas the KCU belt includes imbricate sheets of Paleozoic metamorphic and igneous rocks, and Mesozoic sedimentary covers. The KCU and SMU belts formed during Cenozoic (i.e., Alpine-Apenninic orogenesis) as a unique south and SE verging accretionary wedge that grew upon the Meso-Cenozoic sequences of the African margin (i.e., the Hyblean foreland, Figure 1b). Most of the KCU imbrication occurred by the deposition of the lower Miocene Stilo-Capo d'Orlando terrigenous sequence [Bonardi et al., 1980; Nigro, 1996]. Afterward, during Miocene, the tectonic transport of the KCU belt toward the southeast occurred passively above a sole thrust in the underlying SMU units, and only a subordinate amount of contractional strain was accommodated within the KCU belt by breaching thrusts and transpressional faults, including the Tindari Fault System [Giunta and Nigro, 1999]. In mid-Pliocene, a contractional tectonic event produced widespread thrusting and folding in the central Sicily [Barbano et al., 1978] and a reactivation of strike-slip faults in the northeastern Sicily, including the reactivation of the Tindari Fault System [Ghisetti, 1979]. In the southern Sicily, the tectonic activity at the front of the thrust belt (i.e., the Gela Nappe) ceased gradually during mid-Pleistocene [Butler et al., 1992;
Lickorish et al., 1999], possibly because of the resistance to subduction of the thick and buoyant Hyblean-Pelagian lithosphere. In contrast, earthquakes and GPS data show that the contractional processes are still active in the CalabrianIonian compartment and in a recently formed E-W striking thrust belt in the southern Tyrrhenian Sea (i.e., to the northwest of the Tindari Fault System, Figure 2) [Goes et al., 2004; Montone et al., 2004; Pondrelli et al., 2004].

[9] The opening of the Tyrrhenian back-arc basin produced widespread extension in the offshore northern Sicily, where NW-SE to E-W striking normal faults of late Miocene age have partially dissected the tectonic wedge to form extensional basins (e.g., the Cefalù Basin located to the west of Tindari, see Pepe et al. [2000]). Since late Miocene, the extensional tectonics propagated toward the south and southeast and progressively involved the present-day coastal areas of the northern Sicily. In particular, in the northeastern Sicily and near offshore areas, extensional basins developed since late Miocene [Catalano et al., 1996; Pepe et al., 2000] mostly along north to NE striking extensional faults [Ghisetti, 1992; Di Stefano and Lentini, 1995; Lentini et al., 1995, 1996], in response to WNW-ESE and NW-SE oriented stretching processes [Cifelli et al., 2004]. Generalized stretching continued during the middle (?)-late Pliocene, this regime causing widespread normal faulting [Fabbri et al., 1981; Barone et al., 1982] and crustal thinning [Pepe et al., 2000, 2004].

[10] Volcanism in the Tyrrhenian Sea migrated southeastward following the rollback of the Ionian slab [Sartori, 1990; Argnani and Savelli, 1999]. Oceanic crust emplacement occurred first in the Vavilov basin $(\sim 3-4 \mathrm{Ma})$ and then shifted toward the east in the Marsili basin ( $\sim 2 \mathrm{Ma})$ [Sartori, 1990]. The volcanic activity of the Aeolian Islands started about 1.3 Myr ago and is still active on three of the seven major islands, namely Lipari (last eruption in 729 AD), Stromboli (persistently active), and Vulcano (last eruptions in 1888-1892) [Beccaluva et al., 1985; Peccerillo, 2003]. Toward the south, volcanism in the Etnean area started at about $0.5 \mathrm{Ma}$ with tholeiitic magmas. The modern volcano has formed by a succession of volcanic edifices consisting in alternating pyroclastic and effusive rocks [Romano, 1983]. The source of the Mt Etna magmatism is possibly connected with a mantle plume that Montelli et al. [2004] imaged, by seismic tomographies, as shallower than $1000 \mathrm{~km}$.

[11] The Tindari Fault System (Figures 1 and 2) cuts across the western sector of the KCU belt, near the main frontal thrust marking the contact between the KCU and the SMU thrust sheets (i.e., the Taormina line [see van Dijk and Okkes, 1991; Bonardi et al., 2001]). Since at least the early Miocene, the Tindari Fault System and several other NW striking faults across Sicily and Calabria acted as accommodation zones (i.e., as tear faults or thrust lateral ramps) parallel to the tectonic transport during the southeastward migration of the KCU and SMU thrust sheets [Rehault et al., 1987; Dewey et al., 1989; van Dijk and Okkes, 1991; Bonardi et al., 2001]. The activity of the Tindari Fault System has endured until the Quaternary by accommodating strike-slip and extensional displacements [Atzori et al., 
1978; Ghisetti, 1979]. Along the Tindari Fault System, in particular, Ghisetti [1979] assessed more than 6-7 km of right-lateral stratigraphic separation for the KCU metamorphic units, and about 50-60 $\mathrm{m}$ of throw for the upper Pleistocene sediments. East-west, deep seismic soundings (DSS) profiles along the northeastern Tyrrhenian coast of Sicily [Scarascia et al., 1994; Ventura et al., 1999] and earthquake $P$ wave velocity models [Neri et al., 2002] show that across the Tindari Fault System, the Moho deepens toward the west to more than $25 \mathrm{~km}$ from about $20 \mathrm{~km}$ in the east.

[12] In the northeastern Sicily, a further, seismically very important fault is the Messina Straits Fault (Figure 2). This is an offshore normal fault, which was probably responsible for the devastating 1908 earthquake (maximum MCS intensity of XI and approximate magnitude of 7.3), which caused a great tsunami and more than 100,000 casualties [Valensise and Pantosti, 1992]. D'Agostino and Selvaggi [2004] assessed that Sicily and Calabria are moving apart (i.e., across the Messina Straits Fault) by more than $3 \mathrm{~mm} / \mathrm{yr}$ along the $\mathrm{N} 115^{\circ}$ direction.

\section{Methods and Results}

[13] We henceforth describe the methods used for the data acquisition and analysis, and present the obtained results as sorted by the different acquisition methods. In particular, we present, first, the onshore structural data, second, an offshore seismic reflection profile, and last, the earthquake data.

\subsection{Onshore Structural Data}

[14] By field surveys and structure mapping at the 1:25,000 scale, we studied the Tindari Fault System between the northern coast of Sicily (i.e., Tindari-Barcellona area) and the southern termination of the fault system (Figure 3). In the field, we collected data about the geometry and kinematics of fault surfaces and relative striations in 68 measurement sites distributed between the TindariBarcellona coastal area, in the north, and the area of Novara, in the south (Figure 3). Field evidence showed that toward the south, the Tindari Fault System fades $6-7 \mathrm{~km}$ to the southeast of Novara (Figure 3). In the fault termination area, transcontractional domains (i.e., positive flower structures) developed along NW striking fault segments of the Tindari Fault System. These structures are characterized by the juxtaposition of Mesozoic carbonate rocks over a polygenic conglomerate of Oligocene age [see also Lentini et al., 2000]. In map view (Figure 3), the greatest transcontractional domain is about $1200 \mathrm{~m}$ long and $500 \mathrm{~m}$ wide. The transcontractional structures observed near Novara (e.g., in Figure $4 \mathrm{a}$ ) are characterized by a major $\mathrm{N} 120^{\circ}$ striking set of strike-slip and transcontractional faults and associated, low-angle, contractional and transcontractional faults striking $\mathrm{N} 10^{\circ}, \mathrm{N} 45^{\circ}, \mathrm{N} 80^{\circ}$ and $\mathrm{N} 160^{\circ}$.

[15] Toward the north, the Tindari Fault System broadens into a swarm of NNW-SSE, N-S, and NNE-SSW extensional and strike-slip faults, which form a triangular tectonic depression (i.e., the Tindari-Barcellona tectonic depression in Figure 3). The vertices of this depression are near the towns of Tindari and Barcellona along the coastal area, and, in the south, near the town of Novara. In the TindariBarcellona depression, the substructure prerift rocks consist of middle-upper Miocene terrigenous deposits lying on top of Mesozoic carbonates and metamorphic rocks (i.e., mostly marbles) [Lentini et al., 2000]. The sedimentary infilling of the Tindari-Barcellona depression consists of upper Pliocene-Pleistocene, shallow water sediments, in which north and NNE striking synsedimentary extensional faults occur [see also Di Stefano and Lentini, 1995; Cifelli et al., 2004].

[16] Faults forming the Tindari Fault System are steeply inclined surfaces (i.e., $\geq 60^{\circ}$ ) dipping either eastward or westward (Figure 3). These faults have predominantly extensional dip-slip kinematic features and subordinately strike-slip ones (see plots 1 and 2 in Figure 3). The sense of strike-slip movements is preferentially right lateral on the $\mathrm{N} 140^{\circ}$ striking surfaces (see plot 4 in Figure 3) and leftlateral on the $\mathrm{N} 10-20^{\circ}$ striking surfaces (see plot 5 in Figure 3). The extensional faults strike preferentially $\mathrm{N} 10^{\circ}$ and $\mathrm{N} 150^{\circ}$ (see plot 3 in Figure 3). In the field, we observed that the strike-slip faults usually abut against the $\mathrm{N} 150^{\circ}$ trending set of extensional faults. Several fault surfaces show double striations, i.e., strike slip and extensional dip slip. On the fault surfaces where double striations occur, the dip-slip striations overprint the strike-slip ones (Figure 4b). Moreover, faults with extensional dip-slip kinematic indicators occur solely within or at the boundaries of the Tindari-Barcellona coastal depression, usually in association with preexisting strike-slip striations (see plot 6 in Figure 3). To the south of the Tindari-Barcellona coastal area, the Tindari Fault System mostly consists of strike-slip fault surfaces with no evidence of extensional dip-slip movements (see plot 7 in Figure 3). Along the Tindari Fault System, the prerift rocks (i.e., pre-upper Pliocene rocks) are affected by strike-slip and extensional faults. In contrast, the synrift upper Pliocene-Pleistocene sedimentary sequence of the Tindari-Barcellona depression is affected only by extensional faults (among which several are synsedimentary) with no evidences of strike-slip displacements.

[17] To detect the geomorphologic expressions of neotectonic faulting, we analyzed a set of stereoscopic aerial photographs (at the approximate scale of 1:25,000) covering a broad region of the northeastern Sicily (see Figure 2 for location of the area investigated by aerial photographs). The analyzed aerial photographs showed a set of prominent geomorphologic lineaments (in the sense of Ollier [1981]) in the coastal area between Patti and Barcellona (Figure 3). The observed lineaments coincide with linear escarpments trending between NNW-SSE and NNE-SSW [see also Ghisetti and Vezzani, 1978; Ghisetti, 1979]. The morphological throw along the escarpments is between a minimum of $20-30 \mathrm{~m}$ and a maximum of about $300 \mathrm{~m}$. The length of lineaments is between about 500 and $4000 \mathrm{~m}$, and their spacing is between about 200 and $2000 \mathrm{~m}$. Field structural surveys showed that the detected lineaments coincide with fault-controlled linear escarpments (Figure 3). 


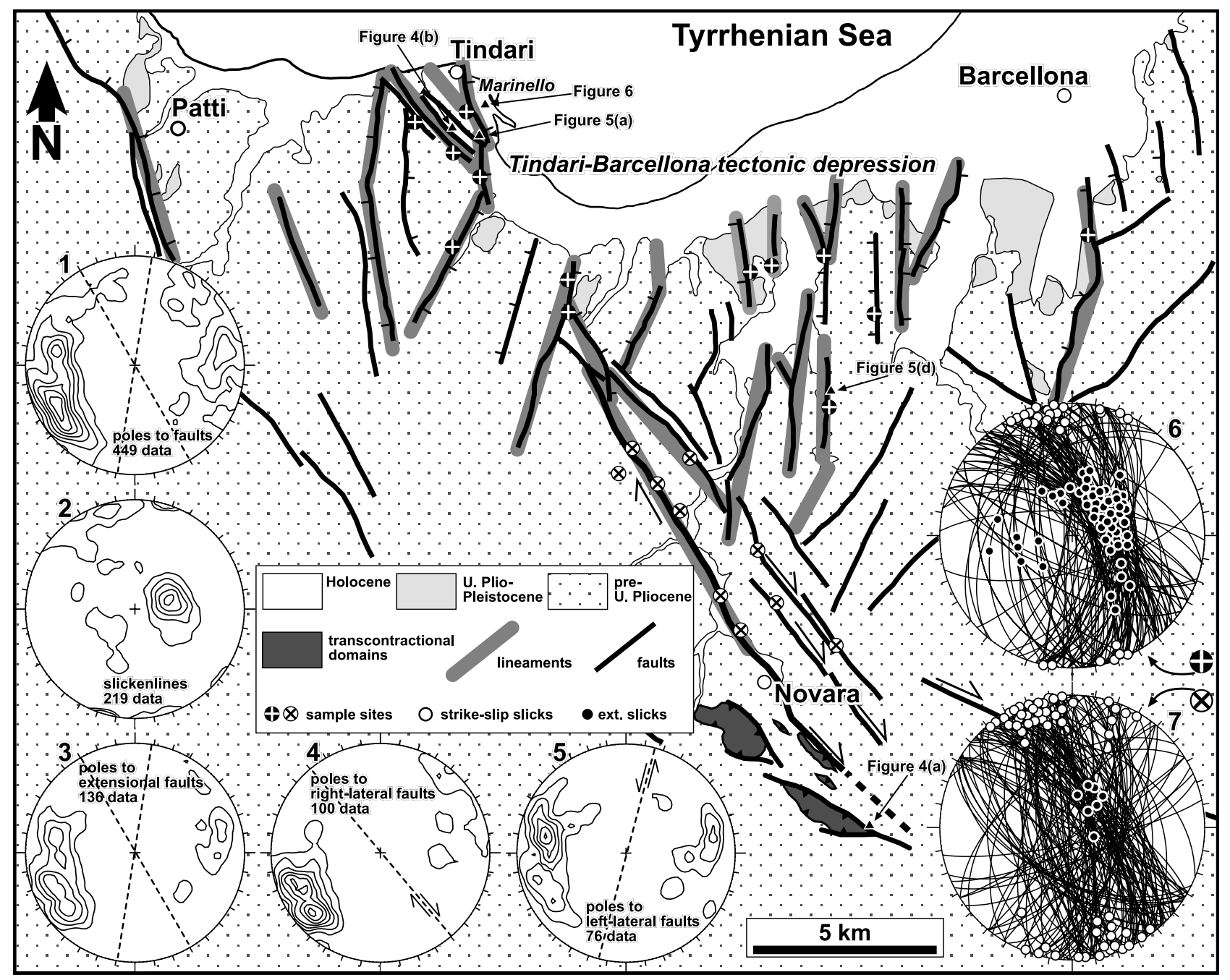

Figure 3. Structural map of the onshore sector of the Tindari Fault System (see Figure 2b for location). Plots (equal-area Schmidt nets, lower hemisphere) 1, 2, 3, 4, and 5 show contours to structural data collected along the Tindari Fault System: 1, poles to all faults; 2, slickenlines; 3, poles to extensional faults; 4, poles to right-lateral faults; 5, poles to left-lateral faults. Dashed lines within plots indicate major strikes of faults. Plots 6 and 7 show faults and related kinematic indicators (i.e., striations indicated as white dots when strike slip, and as black dots when extensional dip slip) collected in the coastal area and in the southern area, respectively (see locations of related sample sites indicated with different symbols). These plots show that strike-slip indicators are common along the entire Tindari Fault System, whereas extensional dip-slip indicators are restricted to the Tindari-Barcellona coastal depression. Note also that the geomorphologic lineaments are restricted to the coastal region between Patti and Barcellona. Note locations (i.e., black triangles) of exposures shown in Figures 4, 5, and 6.

[18] During field surveys, we observed evidences of neotectonic faulting on several exposures within the Tindari-Barcellona depression or at its edges. Figure 5 shows two examples of neotectonic faulting (see Figure 3 for locations of exposures shown in Figure 5). In the first example (Figures 5a, 5b, and 5c), an extensional, NNW striking and ENE dipping fault near Tindari deforms the present-day talus deposited over the main fault surface that is hosted in marble formations of the KCU belt. Similarly, the north striking extensional fault shown in Figures 5d, 5e, and $5 \mathrm{f}$ deforms the present-day talus and soil that developed over the main fault surface, which is hosted in the KCU marbles.

[19] We observed further neotectonic deformations at Marinello (Figure 6), which is a beach area lying on the hanging wall of an extensional segment of the Tindari Fault System near Tindari (see location of Marinello in Figure 3). In the Marinello area, beach rocks consisting of wellcemented gravel and sand are exposed along the perimeters of back-dune coastal lakes (Figure 6). A topographic map of the Tindari-Marinello area carried out in 1877 by the Marina Militare Italiana (i.e., the Italian Navy) shows that 


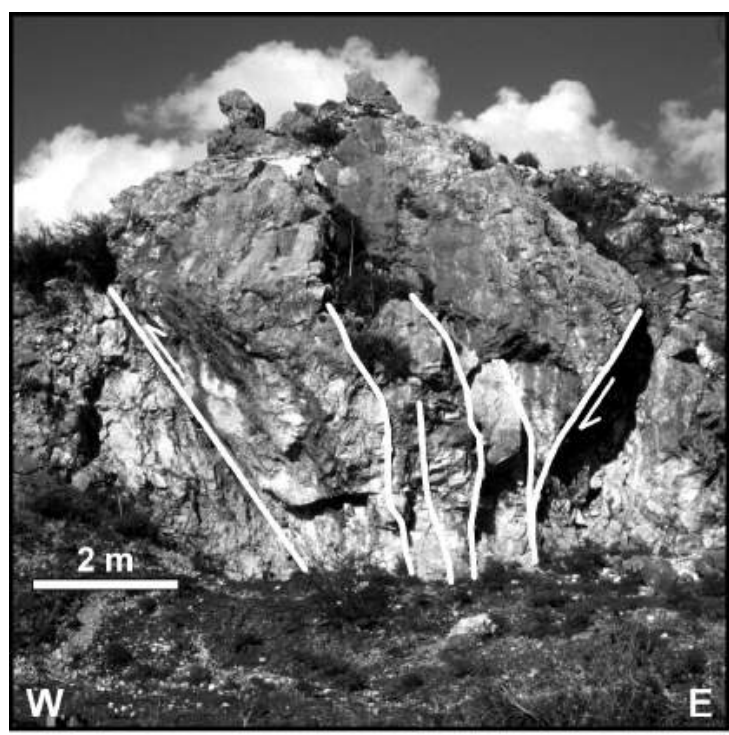

(a)
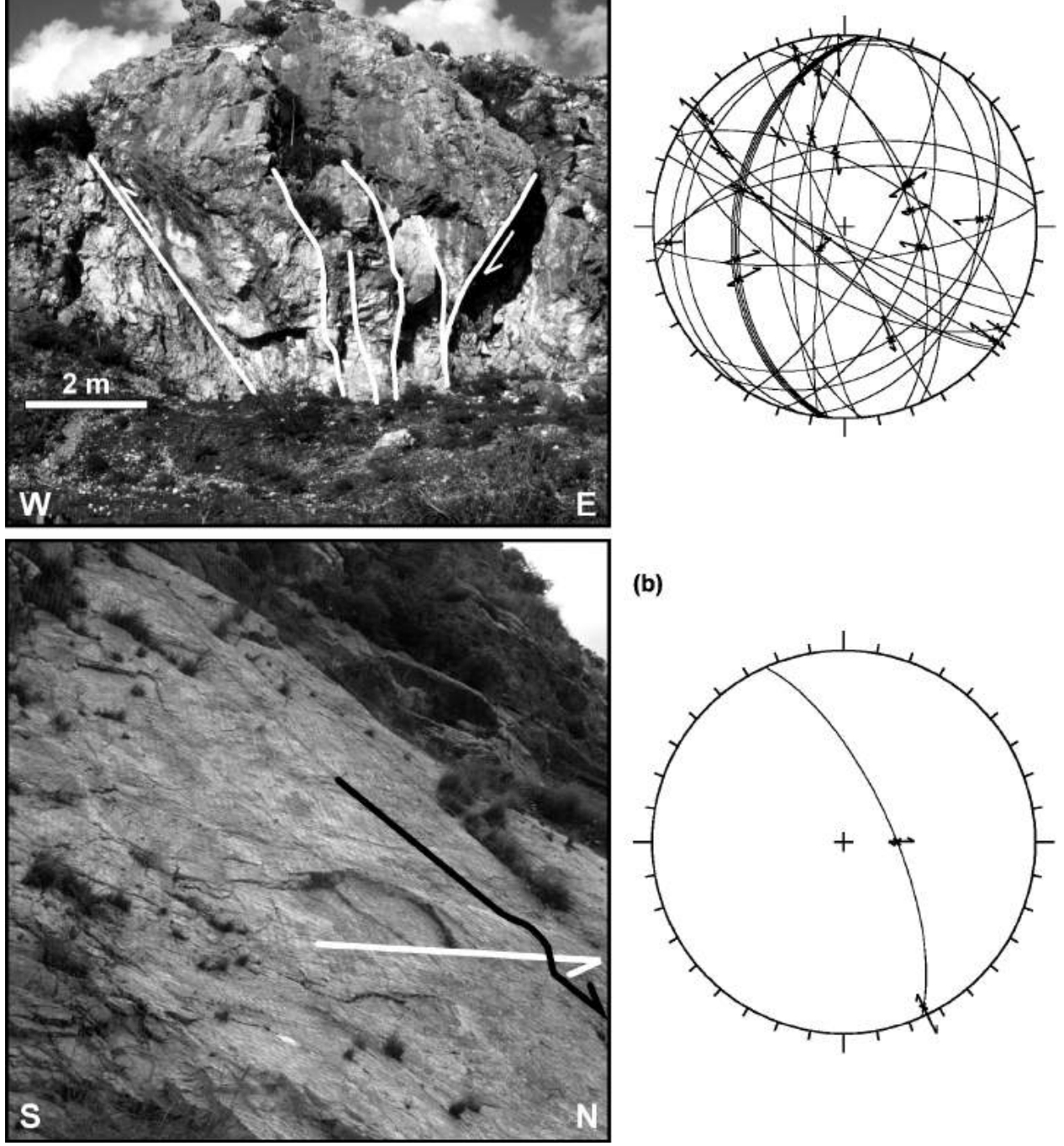

(b)

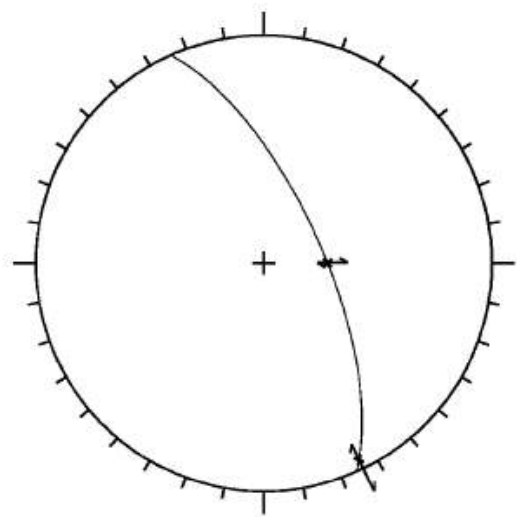

Figure 4. (a) Photograph of a positive flower structure located south of Novara (see Figure 3 for location). The equal-area Schimdt net (lower hemisphere) on the right shows the related structural data (i.e., fault planes and related slickenlines). (b) Photograph of a NNW striking fault surface exposed in the Tindari area (see Figure 3 for location). The surface is exposed on marbles of the KCU units. Arrows on the fault surface highlight the kinematic indicators. Dip-slip striations (black arrow) overprint strike-slip spikes (white arrow). The equal-area Schimdt net (lower hemisphere) on the right shows the related structural data (i.e., fault planes and related slickenlines).

the present-day Marinello beach formations were totally absent at that time [Barbagallo, 2003]. This document allows to date the Marinello beach rocks back to less than about 120-130 years. In June 2002, during a structural survey on the Marinello area, we observed and measured sets of subvertical extensional fractures affecting the exposed beach rocks (Figures 6b, 6c, and 6d). Observed fractures are predominantly $\mathrm{N} 145^{\circ}$ and $\mathrm{N} 110^{\circ}$ striking (see rose diagram in Figure 6a). Subordinate sets of fractures strike $\mathrm{N}-\mathrm{S}$ and $\mathrm{N} 20^{\circ}$. On the exposures, the maximum aperture (i.e., the opening displacement perpendicular to the fracture strike) of fractures is about $2 \mathrm{~cm}$, and the length of fractures is between a minimum of $0.1 \mathrm{~m}$ and a maximum of about $5 \mathrm{~m}$.

\subsection{The ST1E Seismic Profile}

[20] We analyzed the ST1E multichannel seismic reflection profile in order to constrain the Tindari Fault System in the offshore area. The profile is $\sim 26 \mathrm{~km}$ long and $\sim \mathrm{N} 87^{\circ}$ oriented (see Figure 2 for location). During seismic prospecting, we used the following hardware components: an air gun 75 cubic inches sound source, a 12-channel streamer with $50 \mathrm{~m}$ interchannel distance, antialias analog filters of $300 \mathrm{~Hz}$. For the relative data acquisition and treatment, we 

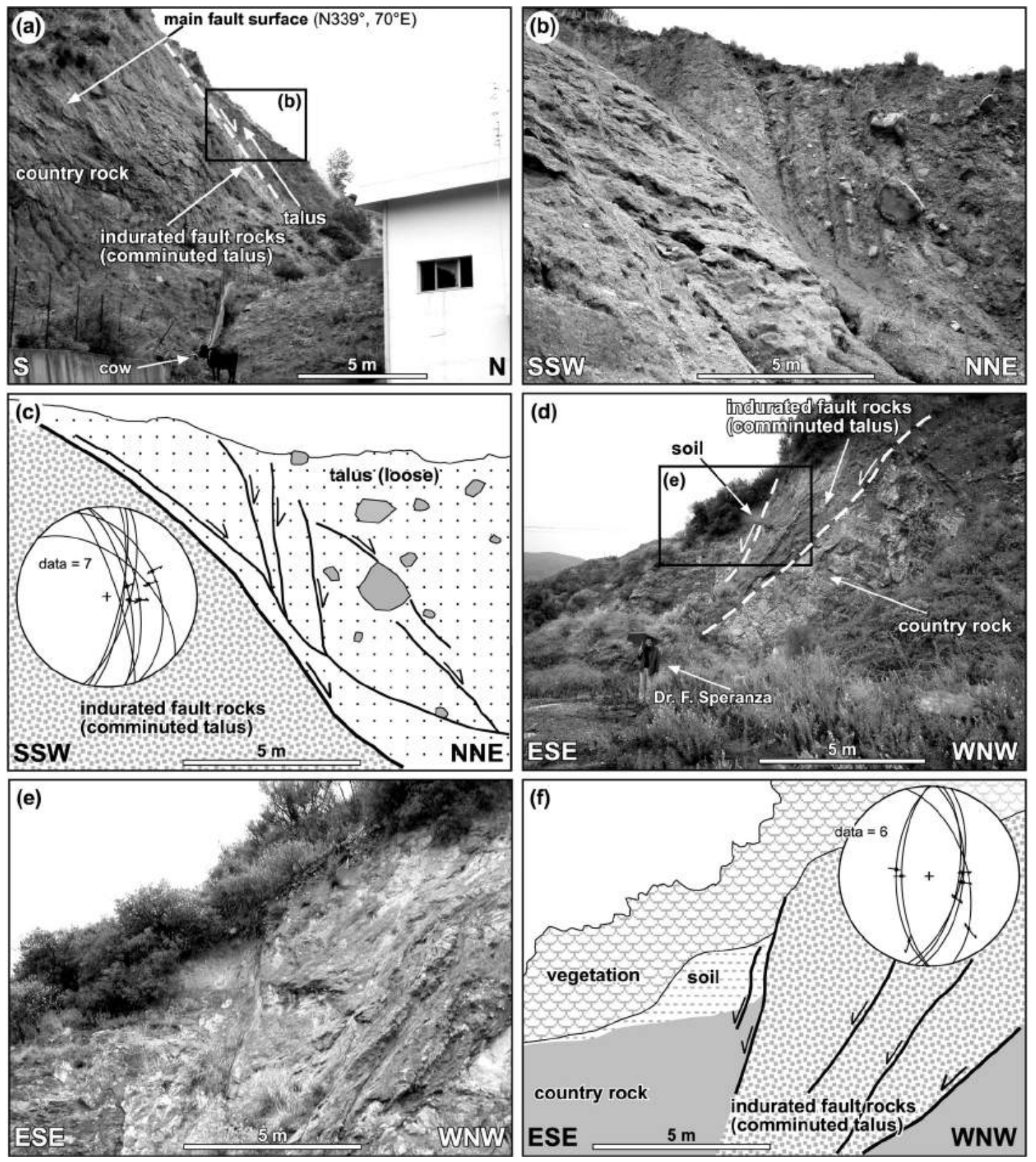

Figure 5. Photographs showing evidences of neotectonic faulting within the Tindari-Barcellona depression (see Figure 3 for locations of exposures). Lines and associated arrows indicate faults with kinematics. (a) A NNW striking extensional fault located south of Tindari. The fault involves the presentday talus and a layer of indurated fault rocks deriving from the comminution of an early talus. The main fault surface is hosted in the country rock (i.e., marbles from the KCU domain). See the cow for scale. (b) Enlargement of Figure 5a. (c) Line drawing of Figure 5b. The equal-area Schmidt net (lower hemisphere) shows fault surfaces and related slickenlines. Strike of fault heave is between $\mathrm{N} 60^{\circ}$ and N95 ${ }^{\circ}$. (d) A N10 ${ }^{\circ}$ striking extensional fault near Rodì. The fault involves a wedge of talus and fault rocks. The fault involves also a wedge of present-day soil that developed over the fault surface hosted in the marbles of the KCU domain. See F. Speranza with umbrella for scale. (e) Enlargement of Figure 5d. (f) Line drawing of Figure 5e. The equal-area Schmidt net (lower hemisphere) shows fault surfaces and slickenlines. Note that faults are mainly extensional dip-slip features characterized by E-W oriented heave. However, the presence of oblique-slip slickenlines over two faults suggests that the extensional slip postdated early oblique-slip movements. One of these faults (i.e., $\mathrm{N} 1^{\circ}$ striking and $60^{\circ}$ dipping westward), in fact, shows double striations (i.e., oblique slip and dip slip). 

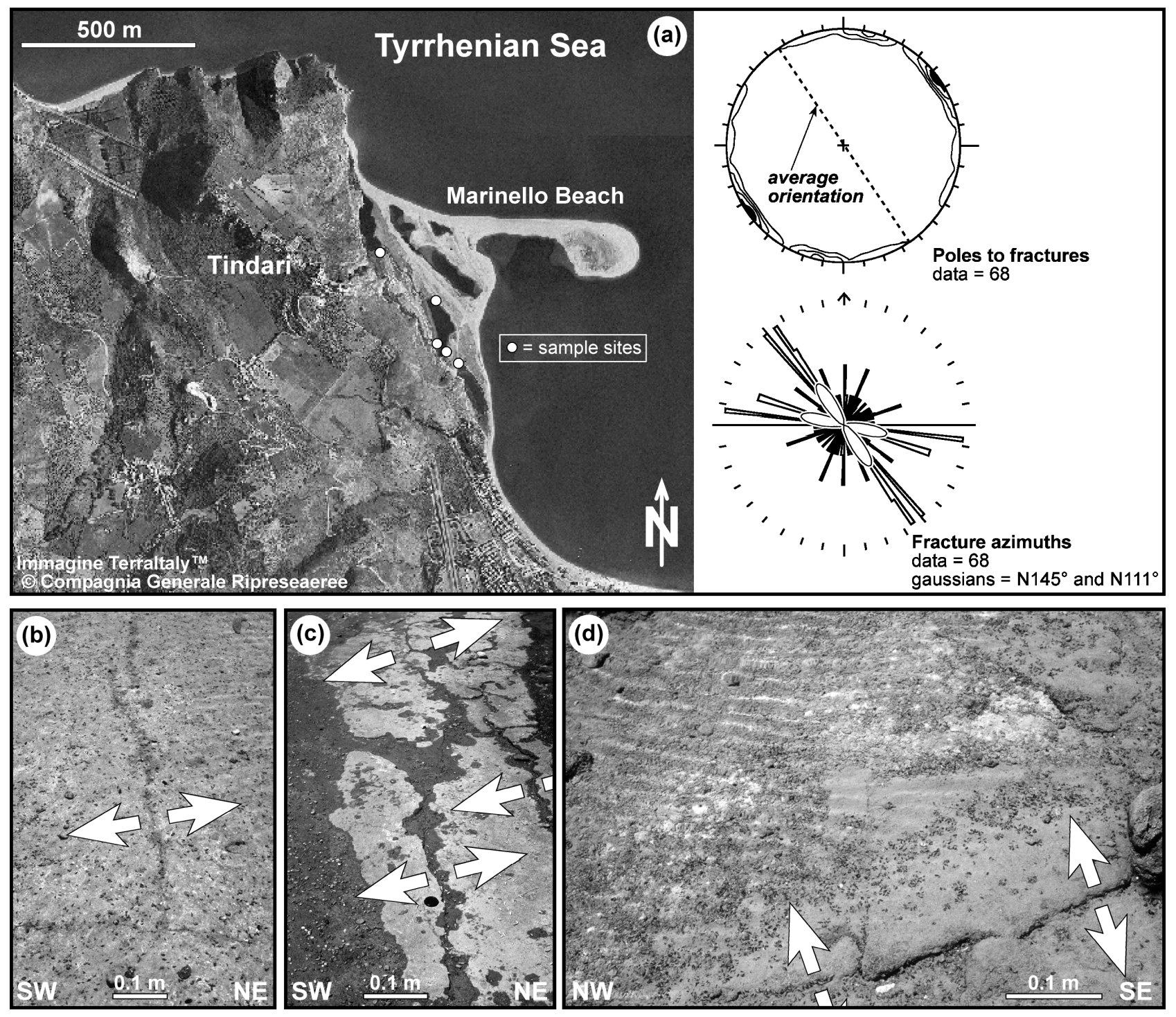

Figure 6. (a) Aerial photograph (Immagini TerraItaly ${ }^{\mathrm{TM}} \odot$ Compagnia Generale Ripreseaeree S.p.A.-Parma, www.terraitaly.it) showing the cliff of Tindari and the Marinello area situated on the hanging wall of a NNW striking extensional segment of the Tindari Fault System along the northeastern escarpment of the Tindari cliff (see Figure 3 for location). White dots indicate sample sites of extensional fractures within beach rocks exposed along the lake perimeters. The equal-area Schmidt net (lower hemisphere) shows contours to poles of the analyzed fractures. Rose diagram shows the histogram and Gaussian best fits of fracture azimuths. Note that preferential azimuths of fractures are $\mathrm{N} 111^{\circ}$ and $\mathrm{N} 145^{\circ}$. (b), (c), and (d) Photographs showing extensional fractures affecting beach rocks exposed in the Marinello area. Arrows indicate direction of opening displacement across fractures.

used the Seismic Treatment Method 96 system [Pepe, 1996]. Both positioning and shot rate $(50 \mathrm{~m})$ were controlled by the NavPro navigation system. Seismic signals were recorded for $5.0 \mathrm{~s}$ two way travels time (TWTT) at 1 ms time rate interval. We processed the raw seismic data to obtain a seismic profile with a resolution suitable for describing, in fine detail, the seismic facies of the tectonic bodies crossed by the profile. This processing included the following mathematical operators: dc removal, geometry definition, velocity analyses, stack of the common depth point (CDP) reflection, traces mixing, time variant gain, spherical divergence correction, and time variant filters. We reduced the sea bottom multiple reverberations and diffractions by applying Surgical Mute and F-K migration, respectively.

[21] In the absence of wells in the investigated area, to define the seismic units we used seismostratigraphic analysis tools and methods calibrated by interval velocity. 


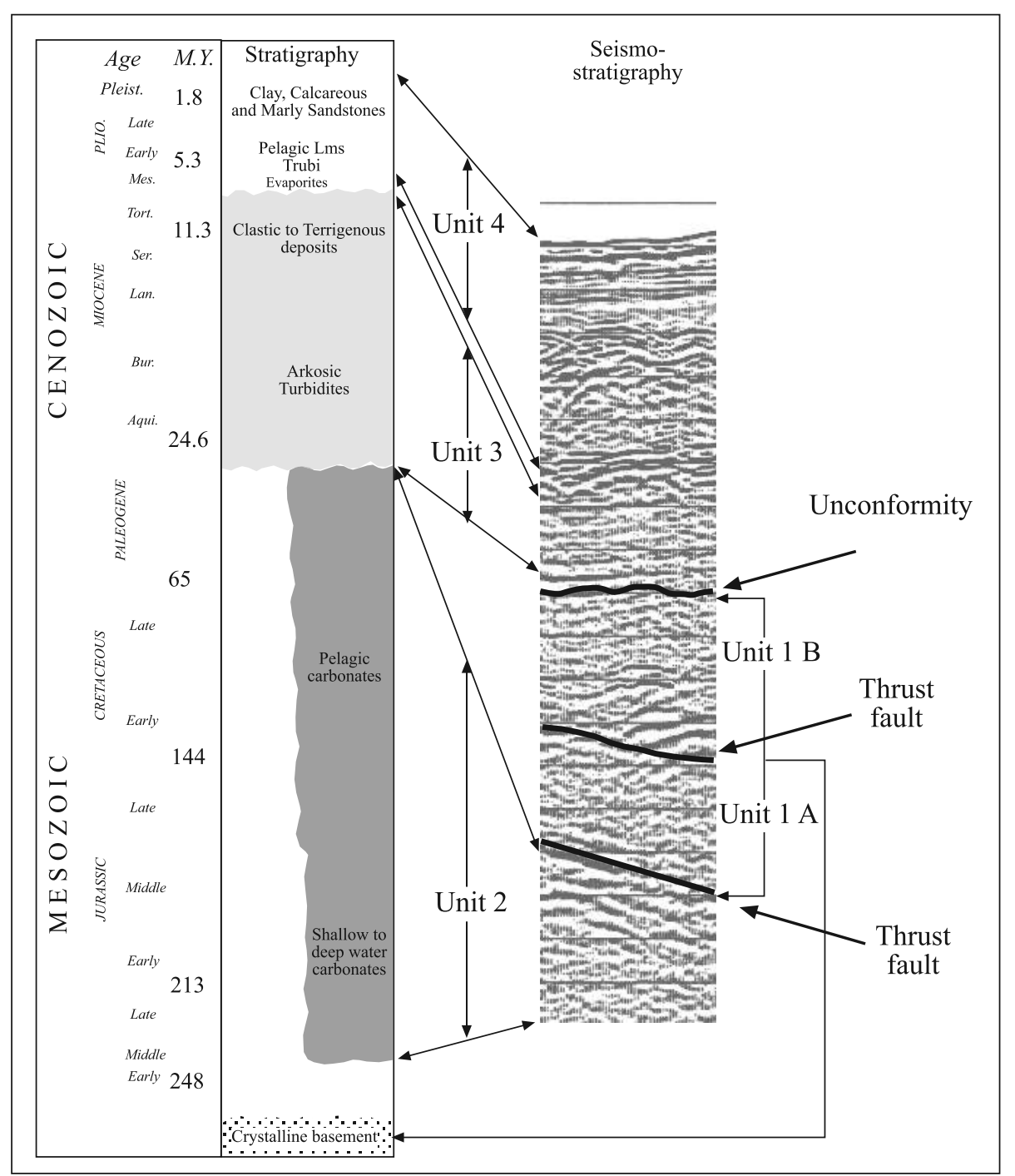

Figure 7. Stratigraphic column for the KCU units (modified from Catalano et al. [1996] with permission) and correlations with the seismic units recognized in the ST1E profile (see the ST1E profile in Figure 8).

Moreover, to infer their lithologies and age, and to make correlations with the stratigraphic successions exposed in the northeastern Sicily, we used data from published seismic profiles [Finetti and Del Ben, 1986] and dredge samples recovered on structural highs close to the study area [Bigi et al., 1991]. Figure 7 summarizes the lithostratigraphic characters for the tectonic units of the $\mathrm{KCU}$ belt as recognized, near the analyzed area, both on land and offshore.

[22] In the ST1E line (Figure 8a), we recognized four seismic units with variable geometry and seismic facies (Figure $8 \mathrm{~b}$ ). Unit 1 is characterized by chaotic to reflection-free seismic facies. Unit 1 is internally subdivided into two subunits (A and B, Figures 7 and $8 \mathrm{~b}$ ) by a highamplitude reflector that could correspond to a detachment or thrust fault. We recognized unit 1 from $\sim 2.5$ to $\sim 3.5 \mathrm{~s}$ TWTT Unit 1 reaches its maximum thickness in the area between the CDP 200 and the CDP 350. Upward, a high- amplitude reflector characterized by a poorly lateral continuity limits unit 1 . We interpreted the seismic facies of unit 1 as a stack of crystalline rocks pertaining to the KCU belt (Figure 7).

[23] A high internal reflectivity and an eastward plunging characterize unit 2. A high-amplitude reflector characterized by a good lateral continuity upward limits unit 2 . We recognized unit 2 between $\sim 2.9$ and $\sim 4.0$ s TWTT in the western sector of the profile. We interpreted this seismic facies as the Meso-Cenozoic carbonate cover of the KCU belt (Figure 7).

[24] Unit 3 is characterized by rhythmic successions of high- and low-amplitude, poorly continuous reflectors. We interpreted unit 3 as the Cenozoic clastic to terrigenous sedimentary cover of the crystalline unit and carbonate succession (Figure 7). Unit 3 is upward limited by a highamplitude, intermediate-frequency, continuous reflector. This key horizon is known over large sectors of the 

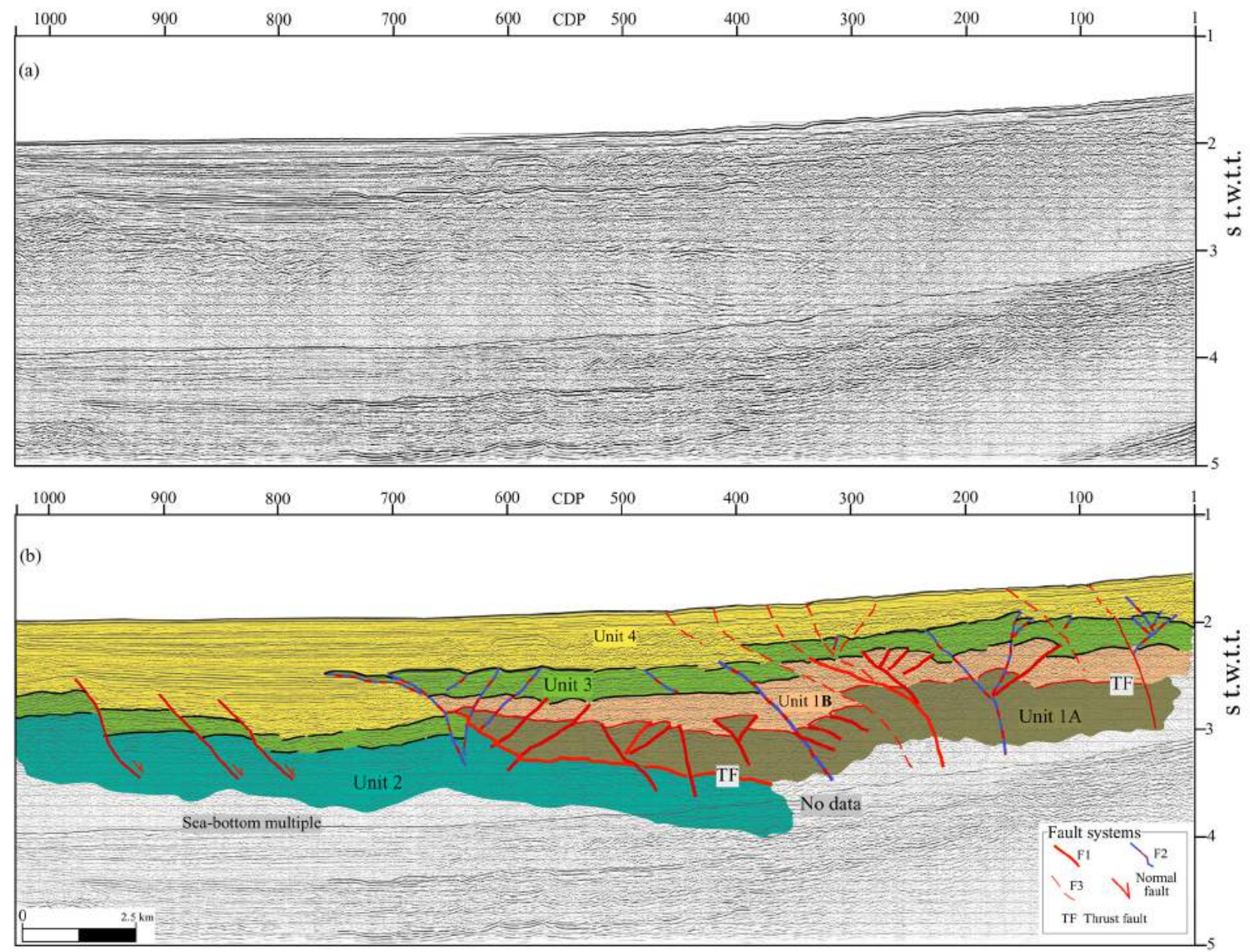

Figure 8. (a) Multichannel seismic reflection profile (ST1E line) acquired offshore the southern Vulcano Island (see Figure 2 for location). (b) Interpretation of the ST1E line showing four units. Unit 1 (1A and 1B) consists of crystalline rocks of the Kabilian-Peloritan-Calabrian (KCU) belt; unit 2 consists of Meso-Cenozoic carbonate cover of the KCU belt; unit 3 consists of Cenozoic clastic to terrigenous cover of the KCU belt topped by Messinian evaporites; and unit 4 consists of Plio-Pleistocene deposits. F1, F2, and F3 are three reverse (possibly transpressional) fault families differentiated by age: F1, active until early Cenozoic; F2, active mostly in the middle-late (?) Pliocene; F3, presently active. TF, thrust faults. Note that three extensional faults in the western sector are sutured by the upper portion of unit 4 . These three faults are not included in the F1, F2, and F3 families.

Tyrrhenian basin [Malinverno, 1981] and Mediterranean region [Ryan et al., 1973] as corresponding to the evaporites deposited during the late Messinian salinity crisis (Figure 7).

[25] The uppermost unit (unit 4) is characterized by wellstratified, high-frequency, high- to low-amplitude reflectors showing a very good lateral continuity. Unit 4 shows a heterogeneous thickness across the profile. Unit 4 unconformably overlies older deposits. We interpreted unit 4 as a Plio-Pleistocene succession (Figure 7) well known in the Mediterranean area [Finetti and Del Ben, 1986]. Note that chaotic signals often covered by diffractions are incorporated in unit 4 . We interpreted these signals as volcanic deposits.
[26] On the ST1E line (Figure 8), we inferred the presence of normal faults (i.e., see the western side of the ST1E line) and the presence of three distinct families of reverse (i.e., possibly transpressional) faults, namely F1, F2, and F3 (i.e., see the central and eastern side of the ST1E line). F1 is the oldest family and consists of reverse faults dipping both westward and eastward. F1 cuts across the stack of crystalline rocks (unit 1), the Meso-Cenozoic carbonate succession (unit 2), and the lowest part of their Cenozoic clastic to terrigenous sedimentary cover (unit 3). F1 appears to be a strike-slip reactivation of the older thrust system that led to the internal stacking of the crystalline rocks (unit 1) and to their tectonic superposition onto the Meso-Cenozoic car- 


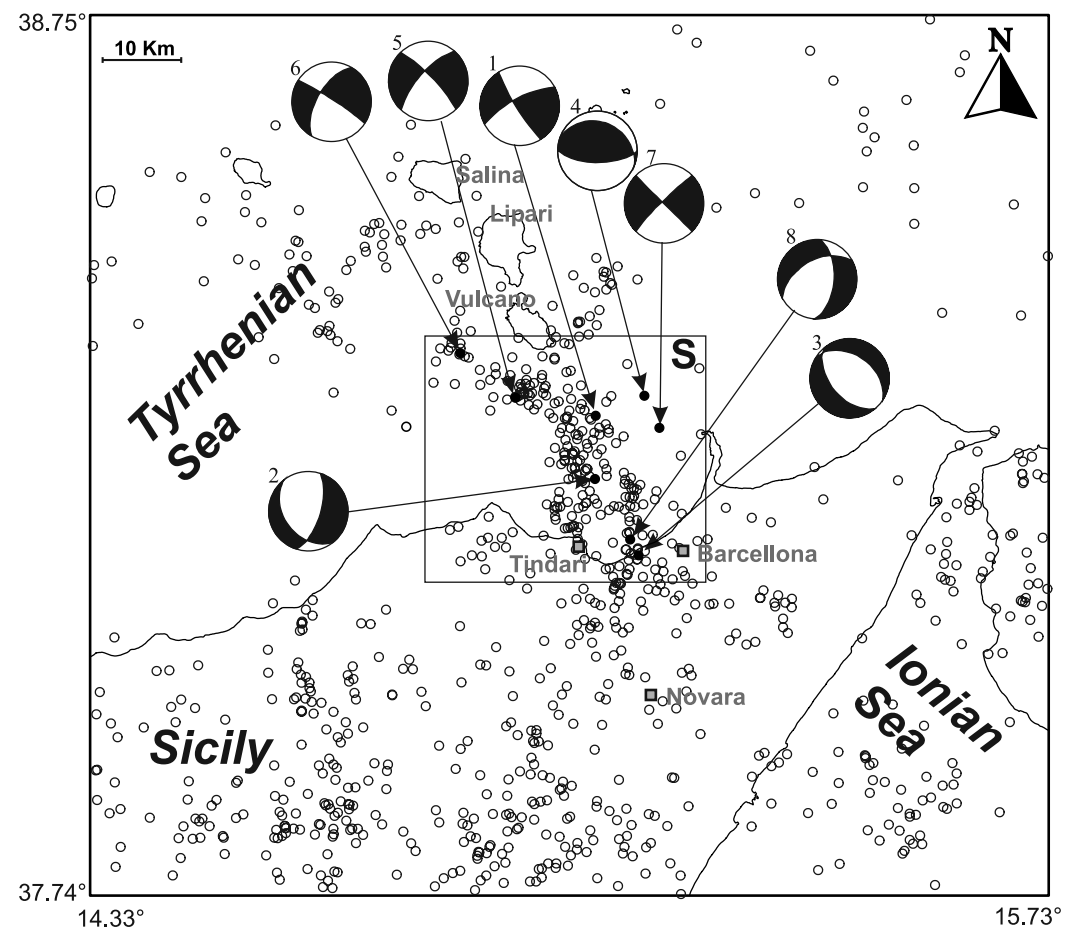

Figure 9. Epicenter map of the earthquakes shallower than $30 \mathrm{~km}$ occurred in the northeastern Sicily and southern Tyrrhenian Sea during 1978-2002. Sector S was the area of greatest earthquake activity during the studied period and is the main subject of the seismological analysis in this paper (see also Figures 10 and 11). The earthquake fault plane solutions with errors on fault parameters less than $20^{\circ}$ available for sector $\mathrm{S}$ are also plotted, with the corresponding focal data listed in Table 1.

bonate succession (unit 2). The geometry of F1 can be depicted as a positive flower structure. Also, the crystalline body (unit 1) plunges eastward and appears to be redoubled in the area of the CDP 350. By using an average seismic velocity of $3000 \mathrm{~m} / \mathrm{s}$, we estimated over $750 \mathrm{~m}$ the maximum vertical separation of the top of the crystalline rocks (unit 1) on these faults. F1 does not significantly offset the upper part of unit 3. For this reason, F1 should have been active until the early (?) Cenozoic times.

[27] F2 consists of high-angle reverse faults, dipping both eastward and westward. F2 cuts across the lower Tertiary to Miocene deposits (unit 3) and across older deposits. F2 cuts also across the lowest part of the PlioPleistocene deposits (unit 4). The F2 faults bound a mound-shaped tectonic body (see Figure $8 \mathrm{~b}$ at CDP 100-400), seemingly as a positive flower structure. By using an average seismic velocity of $2000 \mathrm{~m} / \mathrm{s}$, on F2, we estimated $400 \mathrm{~m}$ of vertical separation of the top of the lowest part of unit 3. By our data, we cannot precisely constrain the age of F2; however, by the crosscutting relationships, we inferred that F2 should have been active during the middle-late (?) Pliocene times.

[28] F3 consists of high-angle reverse faults dipping both eastward and westward. F3 upward propagates as far as the sea bottom (Figure $8 \mathrm{~b}$ ). It follows that F3 may be presently active. The vertical displacement of the Plio-Pleistocene strata (unit 4) across these faults is on the order of a few meters. The F3 faults are progressively younger toward the west.

[29] To the west of the CDP 800, we observed a set of normal faults, which dip toward the east and cut across lower (?) Pliocene deposits and older ones (Figure 8b).

\subsection{Earthquake Data}

[30] By using the seismic data available from the database of the Italian National Network of the Istituto Nazionale di Geofisica e Vulcanologia (available at http:// www.ingv.it) and the local networks managed by the Consiglio Nazionale delle Ricerche (CNR) and by the Cosenza, Messina and Catania universities [Neri et al., 2003], we analyzed the seismic activity located at depths shallower than $30 \mathrm{~km}$ in the northeastern Sicily (Figure 9).

[31] $P$ and $S$ wave arrival times of earthquakes recorded between 1978 and 2002 were elaborated for hypocentral locations using the Evans et al. [1994] algorithm and the three-dimensional crustal velocity model successfully tested in a previous paper [Neri et al., 2002]. Figure 9 displays the epicenter map of earthquakes located with RMS (i.e., standard deviation of arrival time residuals) less than $1.0 \mathrm{sec}$ and GAP (i.e., maximum azimuthal gap of the network around the epicenter) less than $180^{\circ}$. Epicenter and focal depth errors were estimated to be smaller than 3 and $4 \mathrm{~km}$, respectively. Figure 9 shows that the offshore sector of the Tindari Fault System was the most seismic area of the 
Table 1. List of Earthquake Parameters About the Fault Plane Solutions Displayed in Figure $9^{\text {a }}$

\begin{tabular}{|c|c|c|c|c|c|c|c|c|c|c|c|}
\hline Event & Date & Origin Time, UT & Latitude, ${ }^{\circ} \mathrm{N}$ & Longitude, ${ }^{\circ} \mathrm{E}$ & Depth, km & Mag & $\mathrm{AZ1}$ & DIP1 & AZ2 & DIP2 & $\mathrm{F}$ \\
\hline 1 & 15 Apr 1978 & 2333 & 38.290 & 15.070 & 10.00 & 5.5 & 239 & 71 & 147 & 83 & - \\
\hline 2 & 4 Apr 1990 & $1503: 38.70$ & 38.217 & 15.067 & 10.40 & 2.6 & 35 & 65 & 161 & 38 & + \\
\hline 3 & 24 Aug 1993 & 0120:50:52 & 38.133 & 15.128 & 14.07 & 3.0 & 140 & 50 & 305 & 41 & + \\
\hline 4 & 3 Jul 1994 & 0705:06.73 & 38.319 & 15.135 & 28.60 & 3.0 & 90 & 65 & 293 & 27 & - \\
\hline 5 & 7 Jul 1994 & $1403: 59.38$ & 38.321 & 14.980 & 4.80 & 4.0 & 315 & 80 & 225 & 70 & + \\
\hline 6 & 27 Nov 1994 & $0726: 28.14$ & 38.363 & 14.875 & 11.38 & 3.7 & 305 & 85 & 212 & 60 & + \\
\hline 7 & 27 Aug 1995 & $1942: 14.20$ & 38.279 & 15.165 & 8.91 & 4.0 & 225 & 85 & 135 & 90 & - \\
\hline 8 & 29 May 2000 & $1425: 31.86$ & 38.153 & 15.118 & 9.03 & 3.0 & 5 & 55 & 241 & 51 & + \\
\hline
\end{tabular}

${ }^{\mathrm{a}} \mathrm{N}$, order number; latitude, northern latitude of epicenters; longitude, eastern longitude of epicenters; Mag, magnitude; AZ1 and AZ2, azimuth of the nodal planes; DIP1 and DIP2, dip of the nodal planes; F, dip component of slip (minus stands for reverse; plus stands for normal).

northeastern Sicily during the period of analysis (19782002). The $M=5.5$ earthquake of 15 April 1978 (i.e., datum 1 in Table 1 and fault plane solution 1 in Figure 9) represents the seismic event with the highest magnitude during 1978-2002 [Neri et al., 1996]. We recognized a high concentration of seismic events in the central part of the map (sector $\mathrm{S}$ in Figure 9), which includes the northern sector of the Tindari-Barcellona tectonic depression and its offshore area. In sector S (Figure 9), by location and proximity, we recognized two main groups of earthquakes (see shaded areas in Figure 10a): (1) the boomerangshaped group located between Tindari and Vulcano Island and (2) the north trending, quasi-linear group located to the northwest of Barcellona (designated with T3). Within the boomerang-shaped group (i.e., the western one), we recognized two quasi-linear subgroups: the northern subgroup, which strikes about $\mathrm{N} 120^{\circ}$ and is designated with $\mathrm{T} 1$, and the southern subgroup, which strikes about $\mathrm{N}-\mathrm{S}$ and is designated with T2. The eastern group is designated with T3 (Figure 10a). T1 approximately coincides with the southeastern prolongation of the Sisifo Fault, a N120 $0^{\circ}$ striking right-lateral strike-slip fault identified to the northwest of the analyzed area (Figure 2) by seismic reflection methods [Finetti and Del Ben, 1986]. T2 shows an overall N-S orientation. Within $\mathrm{T} 2$, we recognized possible subgroups striking NNW-SSE (Figure 9); however, the available data were not sufficient for such a detailed detection of subgroups.
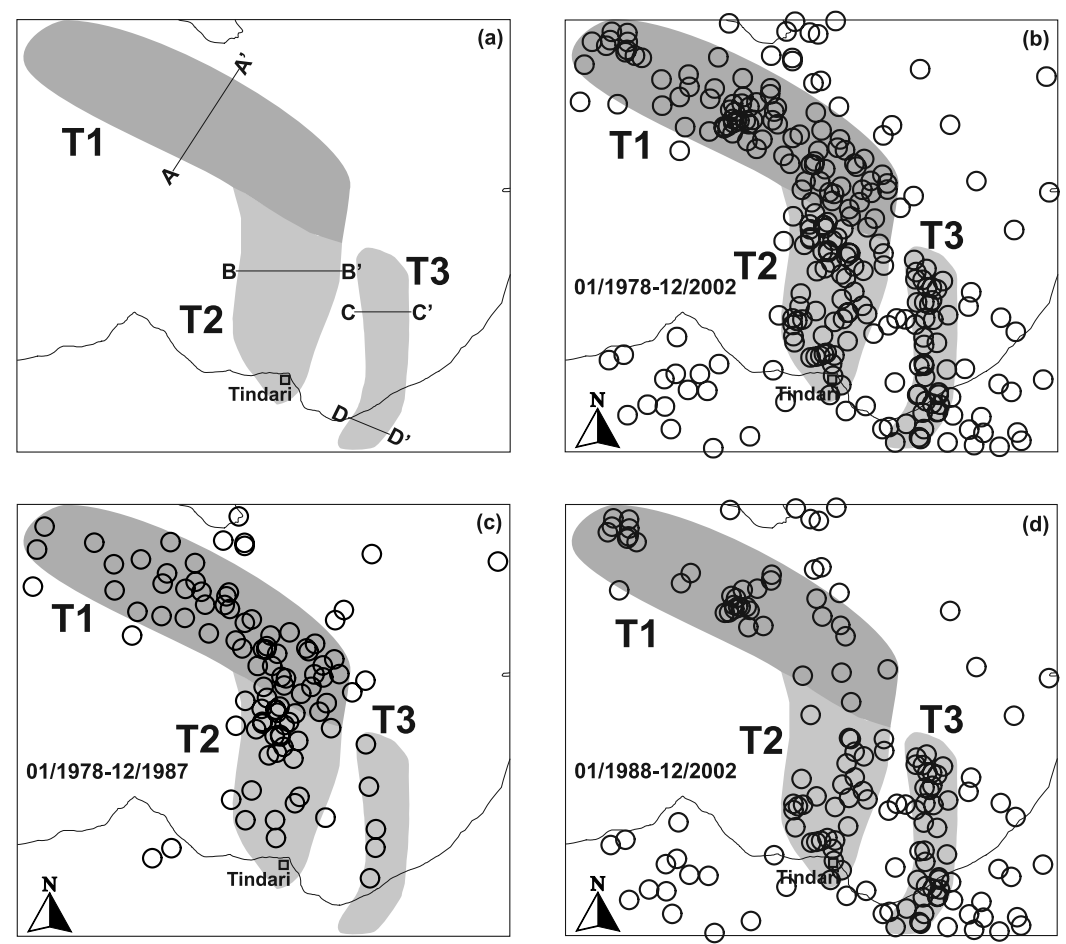

Figure 10. (a) Map indicating the main groups of events discussed in the text (T1, T2, and T3 shaded areas). (b) to (d) Distributions of seismicity sorted by different time intervals: January 1978 to December 2002 (Figure 10b); January 1978 to December 1987 (Figure 10c); January 1988 to December 2002 (Figure 10d). 


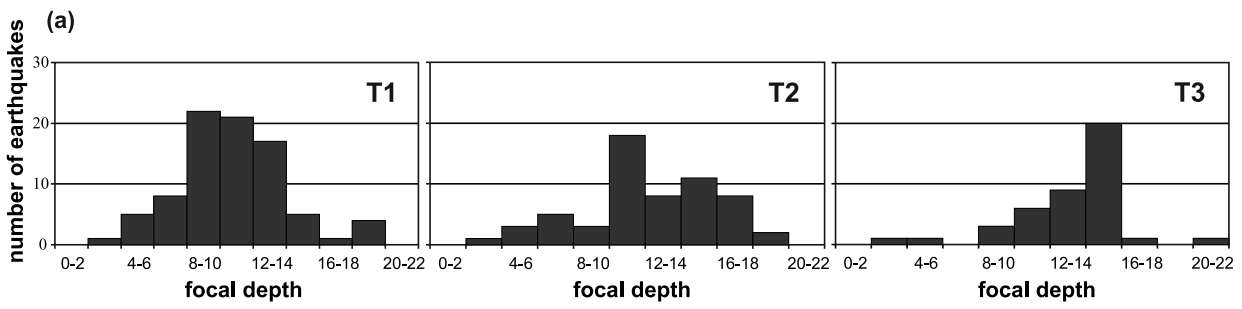

(b)

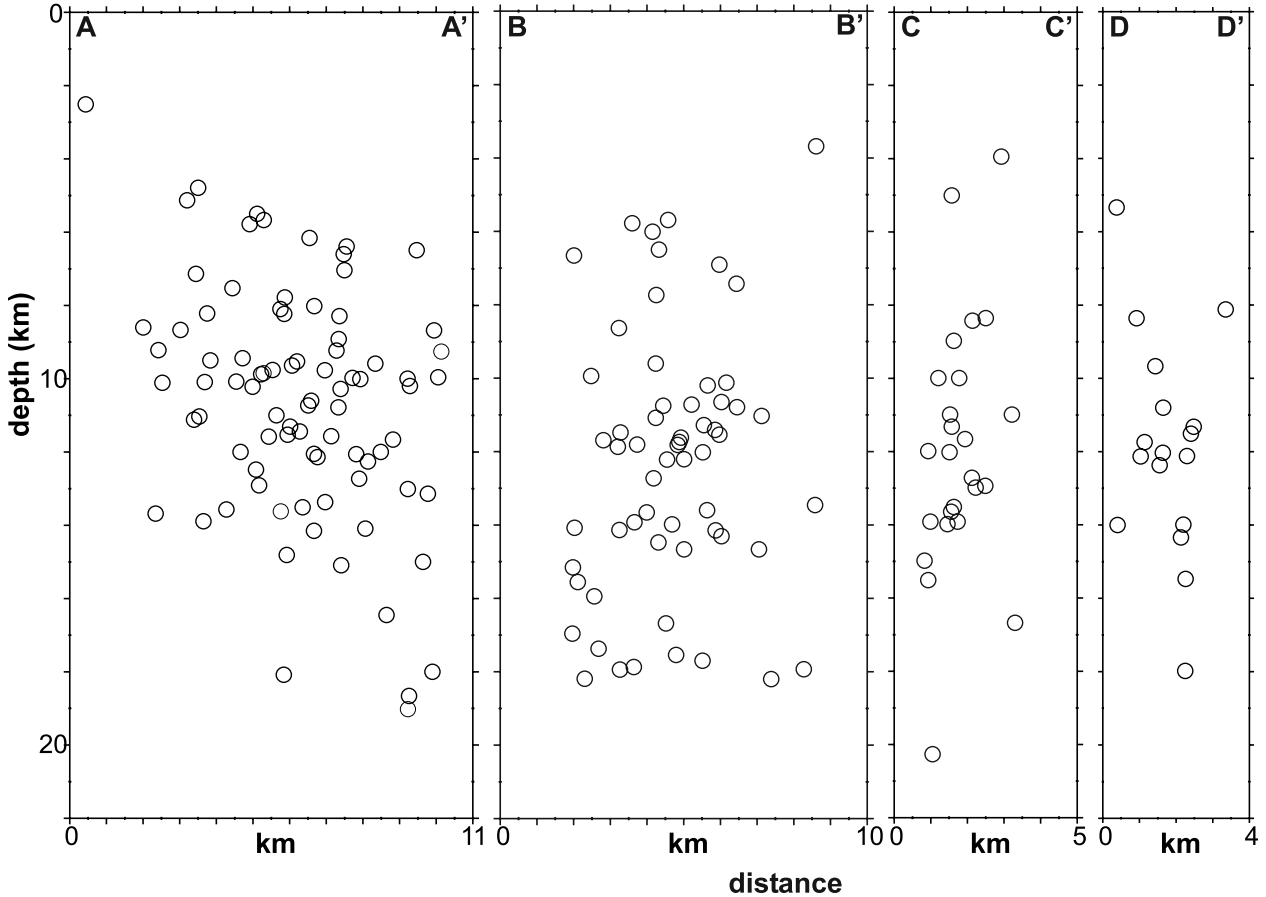

Figure 11. (a) Histograms of focal depths for T1, T2, and T3 groups of earthquakes. Histograms show that in this area, earthquakes occur in the $2-22 \mathrm{~km}$ depth range, with the mean depth equal to $\sim 9 \mathrm{~km}$, $\sim 11 \mathrm{~km}$, and $\sim 15 \mathrm{~km}$ for T1, T2, and T3, respectively. (b) Vertical sections across T1, T2, and T3 (see Figure 10a for section locations) showing hypocentral depths. These sections show that T1, T2, and T3 are zones of diffuse deformation.

[32] Seismic events along the Tindari Fault System are very frequent in the offshore area and less frequent in the onshore coastal area (i.e., during 1978-2002, Figure 9). Only a few events locate along the central and southern onshore sector of the Tindari Fault System (Figure 9).

[33] Figure 9 displays the fault plane solutions estimated with fault parameter errors less than $20^{\circ}$ for earthquakes in sector S. We listed the relative focal data in Table 1. These data showed that during 1978-2002, right-lateral strike-slip earthquakes occurred within T1 (fault plane solutions 1, 5, and 6 in Figure 9), whereas extensional and obliqueextensional earthquakes occurred within $\mathrm{T} 2$ and $\mathrm{T} 3$ (fault plane solutions 2, 3, and 8 in Figure 9). Fault plane solutions 4 and 7 in Figure 9 are in the junction zone between $\mathrm{T} 1$ and $\mathrm{T} 3$ and may pertain to one of them.

[34] Figures 10b to 10d display the spatial distribution of seismic events in sector $\mathrm{S}$ as sorted by time intervals. Figure $10 \mathrm{~b}$ shows the entire set of data collected during 19782002 (i.e., same as Figure 9a). Figures 10c and 10d refer to the 1978-1987 and 1988-2002 time intervals, respectively. These temporal sequences of earthquakes showed noncontemporary activities of T1, T2, and T3. In particular, T1 and the northern part of T2 were intensely active during 19781987, whereas T3 and south T2 were active during 19882002. Further plots of seismic events not reported here for conciseness revealed that $\mathrm{T} 1$ and the northern part of $\mathrm{T} 2$ were significantly active during 1978-1979, and that the seismic activity on T3 and the southern sector of T2 was rather uniform during 1988-2002, with clustered events recorded in May 1992 (T3), August 1996 (T3), and February 1999 (southern T2).

[35] Figure 11a shows histograms of focal depths for T1, $\mathrm{T} 2$, and T3. Focal depths are mostly in the $2-18 \mathrm{~km}$ range. A few events reach depths in excess of $18 \mathrm{~km}$ and one event in $\mathrm{T} 3$ reaches a depth in excess of $20 \mathrm{~km}$. Histograms of focal depths show a slight tendency of foci to deepen from the northwest (T1) to the southeast (T2 and T3). Figure 11b shows the same hypocenter location data as in Figure 11a 
plotted on vertical cross sections perpendicular to T1, T2, and to the northern and the southern sectors of T3, respectively (Figure 10a).

\section{Discussion}

\subsection{Present Geometry of the Tindari Fault System}

[36] Ghisetti [1979] thoroughly mapped and depicted the onshore pattern of the Tindari Fault System as consisting in a master array of high-angle, NNW striking faults, and in subordinate, high-angle, north to NE striking faults. Our onshore structural data (Figure 3) are well consistent with this geometrical reconstruction. In the Tindari Fault System, we included also the faults located within or at the boundaries of the Tindari-Barcellona depression, for a maximum width of $\sim 30 \mathrm{~km}$ for the onshore fault system.

[37] At present, two major issues about the present-day geometry of the Tindari Fault System are poorly constrained, namely its terminations and its offshore pattern.

[38] We found evidence of the southern termination of the Tindari Fault System in the area located 6-7 km to the southeast of Novara (Figure 3). It follows that toward the south, the Tindari Fault System does not directly link with the Malta Escarpment (Figure 1) and does not propagate across the Africa-Eurasia destructive plate margin in Sicily, as hypothesized in previous papers [e.g., Lanzafame and Bousquet, 1997]; however, we cannot rule out that the displacement on the Tindari Fault System may be transferred, toward the south, to interconnected faults [e.g., Ghisetti, 1992].

[39] The northern termination of the Tindari Fault System is still unknown. Several published data suggest that toward the north, the fault system should involve the volcanic islands of Vulcano, Lipari, and possibly Salina (Figure 2), and that the active or recently active volcanicity of these islands should be related to pull-apart processes associated to right-lateral strike-slip segments of the Tindari Fault System [Tortorici et al., 1995b; Ventura et al., 1999]. From the data presented in this paper, the northern prolongation of the onshore Tindari Fault System toward the Aeolian Islands is still not straightforward. The ST1E line across the offshore area of Vulcano (Figure 2) shows an array of contractional-to-transcontractional faults located where Tortorici et al. [1995b] and Ventura et al. [1999] drew the southward prolongation of the strike-slip faults observed at Vulcano and Lipari; however, the earthquake data shown in Figures 9 and 10 (i.e., referring to the 1978-2002 interval) show that the $\mathrm{T} 2$ and $\mathrm{T} 3$ seismic belts seismically abut against the WNW striking T1 belt. It follows that by these data, we cannot clearly demonstrate the physical link between the offshore faults that are inferred from the earthquake data (i.e., after T2 and T3 in Figure 10) and the faults imaged on the ST1E line (Figure 8) or documented at Vulcano and Lipari [Nappi et al., 1976; Tortorici et al., 1995b; Ventura et al., 1999].

[40] The cross-sectional views of the T1, T2, and T3 seismic belts (Figure 11) suggest that the offshore portion of the Tindari Fault System consists in near-vertical zones of diffuse brittle deformation rather than in distinct master faults. The diffuse style of brittle deformations (i.e., T1, T2, and T3) is indeed inferred also from the ST1E line (Figure 8), in which recent faults overprint or reactivate an inherited array of faults. T1, T2, and T3 are as thick as $\sim 18-20 \mathrm{~km}$ (Figure 11). This thickness is consistent with the brittle thickness of the continental crust in the periTyrrhenian domain of Sicily [Pasquale et al., 1997]. The tendency of the earthquake foci to deepen slightly from the northwest (T1) to the southeast (T2 and T3) may be related to the well-documented crustal thickening that occurs from the Aeolian Islands toward the Sicily mainland [e.g., Neri et al., 2002]. T2 and T3 lie along the northward prolongation of some north striking fault segments observed onshore (compare Figure 3 and Figure 10) and may therefore be interpreted as being connected with the onshore structures. This inference is also supported by the extensional earthquake fault plane solutions from T2 and T3 (Figure 9), these solutions being consistent with the recent extensional kinematics (i.e., as inferred from the neotectonic field evidences; see Figures 5 and 6) and with the attitude of the corresponding onshore structures. The prolongation of T1 toward the west-northwest approximately coincides with the right-lateral strike-slip Sisifo Fault (see Figure 2) [Finetti and Del Ben, 1986]. The strike-slip fault plane solutions from the $\mathrm{T} 1$ belt (i.e., right-lateral along the $\mathrm{T} 1$ trend, Figure 9) support the hypothesis of a physical link between $\mathrm{T} 1$ and the Sisifo Fault.

[41] Although from the above data we cannot clearly demonstrate the physical link between the onshore or nearoffshore faults, and the faults observed on the ST1E line and documented at Vulcano and Lipari, by the geometry, kinematics, and proximity of these faults, we suggest that they are all included in the Tindari Fault System, except the T1 belt that is inferred as being the likely south-southeastward prolongation of the Sisifo Fault.

\subsection{Tectonic Evolution of the Tindari Fault System}

[42] Several authors hypothesized an early activity of the Tindari Fault System as a thrust lateral-ramp or as a tear fault during the southeastward tectonic transport of the KCU thrust sheets [e.g., Rehault et al., 1987; van Dijk and Okkes, 1991], mostly by or during the early Miocene [Bonardi et al., 1980]. Although the transpressional F1 fault family (i.e., active during early Cenozoic, Figure 8) on the ST1E line locates right at the lateral termination of a thrust involving the KCU units (see TF in Figure 8) and might therefore be interpreted as a thrust lateral ramp, by our data, we cannot clearly confirm or refute the hypothesis of an early activity of the Tindari Fault System as a thrust lateral ramp or as a tear fault. Like Ghisetti [1979], we interpret the NNW striking right-lateral faults and the NNE striking left-lateral ones within the onshore Tindari Fault System (Figure 3) as conjugate faults. The occurrence of conjugate strike-slip faults in a fault system that is as width as $30 \mathrm{~km}$ is apparently in contrast with the hypothesis of the Tindari Fault System as a thrust lateral ramp or as a tear fault, because this class of faults (i.e., the thrust lateral ramps and the tear faults) commonly consists of fault segments that well align along narrow deformation zones parallel to the 
tectonic transport [e.g., Salvini and Vittori, 1982]. Also, the depth of the Tindari Fault System (i.e., $\sim 18-20 \mathrm{~km}$ as inferred from the earthquake data, Figure 11) is not consistent with the geometry of a thrust lateral ramp or of a tear fault, which, by definition, involve only the thrust hanging wall formations. It follows that if the hypothesis of an origin of the Tindari Fault System as a thrust lateral ramp or as a tear fault is correct, the development of the NNE striking conjugate faults and the propagation of the fault system downdip in the thrust footwall must be ascribed to some contractional events later than the fault inception. Ghisetti [1979], for example, claimed that the Tindari Fault System was reactivated during the contractional event occurred in Sicily in mid-Pliocene [Fabbri et al., 1980]. Evidences of this event can be observed also on the ST1E line (Figure 8), which shows a family (F2) of reverse and transpressional faults active during middle-late Pliocene.

[43] The onshore data presented in this paper show, on the Tindari Fault System, an early strike-slip tectonics and a late extensional one, which reactivated the early strike-slip faults (e.g., Figure 4b) and generated new extensional ones in young rocks not affected by the early strike-slip tectonics. In particular, the upper Pliocene-Pleistocene sediments of the Tindari-Barcellona depression are affected only by extensional faults with no evidence of strike-slip tectonics. Most of these faults are synsedimentary [e.g., Di Stefano and Lentini, 1995; Cifelli et al., 2004]. This suggests that the extensional reactivation of the strike-slip Tindari Fault System occurred since the late Pliocene, when the central sector of the Tindari Fault System (i.e., the Tindari-Barcellona depression) underwent an extensional tectonics probably related to the opening of the Tyrrhenian back-arc basin [Cifelli et al., 2004]. The extensional reactivation of the Tindari Fault System involved only the fault segments included in the Tindari-Barcellona depression or located at its boundaries. The extensional tectonics in the TindariBarcellona depression endured until the late Pleistocene at least, as proved by normal displacements affecting sediments of that age [Ghisetti, 1979; Lentini et al., 2000]. On the ST1E line, except for three, east dipping, extensional faults in the western sector (Figure 8), we did not observe any evidence of extensional tectonics; however, in this area, the extensional displacements may have been mainly accommodated on basin-bounding faults located outside the ST1E line. The occurrence of a thick succession of Pliocene-Pleistocene deposits (i.e., unit 4 in Figure 8 b) throughout the entire ST1E line supports the hypothesis of the occurrence of a Pliocene-Pleistocene sedimentary basin whose boundaries are not included in the ST1E line.

[44] The neotectonic field evidences (Figures 5 and 6) and the earthquake data (Figures 9, 10 to 11) show that the Tindari Fault System has been recently and is presently active in its central and northern sectors (i.e., the coastal and offshore areas). The recent and present-day kinematics of the Tindari Fault System is not spatially and temporally homogeneous (e.g., Figure 10). In particular, the faults included in the bulk of the Tindari Fault System (i.e., the faults included in the coastal area of the Tindari-Barcellona depression and those included in the near offshore area along the T2 and T3 belts) are mostly characterized by extensional kinematics (i.e., see the neotectonic evidences and the earthquake fault plane solutions). However, in Figure 9, the earthquake fault plane solutions 4 and 7, located at the junction between the WNW striking T1 belt and the north striking T2 and T3 belts, suggest that also strike-slip and contractional displacements may be presently accommodated along segments of the Tindari Fault System. These displacements are also inferred along the presently or recently active F3 fault family on the ST1E line (Figure 8). Acquisitions of future earthquake data will clarify whether segments of the Tindari Fault System are indeed accommodating strike-slip and contractional displacements.

[45] Recent GPS velocity data from the northern Sicily [Hollestein et al., 2003; D'Agostino and Selvaggi, 2004] allows the estimate of the present, relative motion between the two blocks bounding the Tindari Fault System. By combining the velocity vectors from the MILA station and the FOSS station, in the east and in the west of the Tindari Fault System (Figure 12), respectively, we obtain that the two blocks are moving apart by $\sim 3 \mathrm{~mm} / \mathrm{yr}$ along the $\mathrm{N} 162^{\circ}$ direction. Because of the errors in the original data [Hollestein et al., 2003; D’Agostino and Selvaggi, 2004], this estimate should be considered as fairly accurate. Moreover, the FOSS station is very closed to the Tindari Fault System and may be affected by the fault-related deformations, thus providing a poorly reliable datum. This problem may be overcome by considering a remote station such as the TRAP station (Figure 12). After the velocity vectors from the MILA and TRAP stations, we obtain that the two blocks that bound the Tindari Fault System are moving apart by $\sim 5 \mathrm{~mm} / \mathrm{yr}$ along the $\mathrm{N} 47^{\circ}$ direction. This estimate may be real only by assuming that the entire margin of the northern Sicily is divided into only two blocks, one in the west and one in the east of the Tindari Fault System. The above estimated velocity vectors are consistent with a present, extensional or right-lateral transtensional kinematics along the Tindari Fault System.

[46] From the above discussed data, the tectonic evolution of the Tindari Fault System can be synthesized as follows: (1) a pre-late Pliocene, multiphase, strike-slip and transcontractional tectonics involving the entire fault system; (2) a late Pliocene-late Pleistocene, extensional tectonics involving only the central sector of the system; and (3) a recent and present extensional or right-lateral transtensional tectonics involving the bulk of the NNW striking fault system (i.e., in the central and northern sectors), and a right-lateral strike-slip tectonics involving the southeastward prolongation of the WNW striking Sisifo Fault.

\subsection{Implications for the Regional Tectonics}

[47] Within the regional tectonic context (Figure 12), three major models may explain the ongoing extensional or right-lateral transtensional displacements on the Tindari Fault System.

[48] 1. The ongoing kinematics on the Tindari Fault System may be induced by the extensional tectonics presently occurring in the southeastern Tyrrhenian region. The contrasting directions of extension for the southeastern 


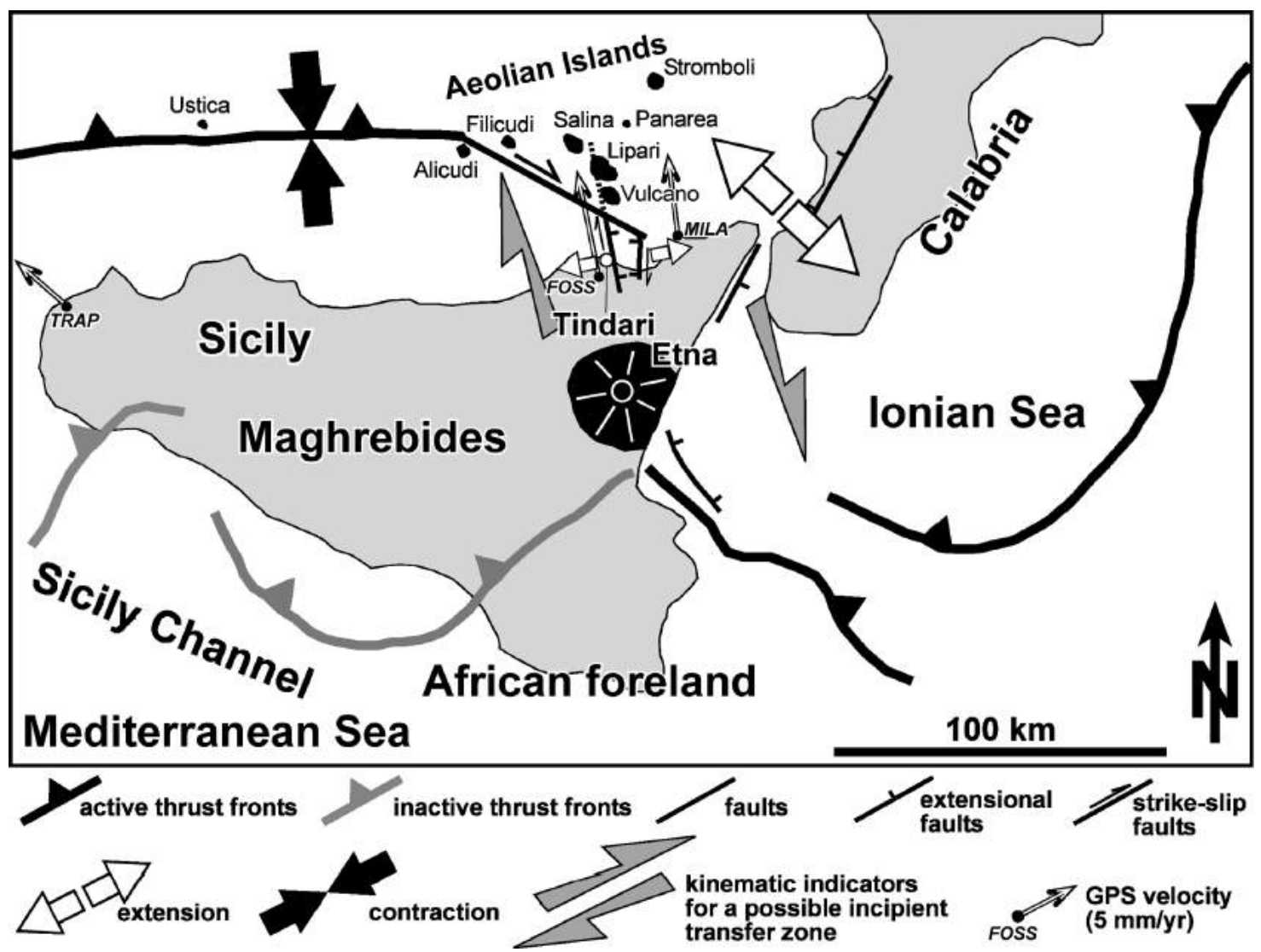

Figure 12. Present-day tectonic setting of Sicily and adjacent areas. The south vergent thrust front in the southern Sicily is inactive since about the mid-Pleistocene. The African convergence is presently accommodated along the SE vergent thrust front in the Ionian Sea and along a recently formed $(\sim 0.5-$ $0.8 \mathrm{Ma}$ ) thrust front (probably south vergent) in the southern Tyrrhenian Sea. In northeastern Sicily, a NNW striking, oblique-extensional, transfer zone linking the active thrust fronts in the Tyrrhenian and Ionian compartments and including the Tindari Fault System may be incipient.

Tyrrhenian region (i.e., about NW-SE [see Neri et al., 2003]) and for the Tindari Fault System (i.e., between about E-W and NE-SW, see data from this paper) may be connected with the presence of north and NNW striking inherited structures along the Tindari Fault System. The extensional reactivation of these structures would, in fact, result in a significant E-W to NE-SW component of normal displacement.

[49] 2. The E-W to NE-SW normal displacement along the Tindari Fault System may be induced by a local stress regime resulting from the combination of the stress regimes acting in the adjacent compartments, i.e., N-S compression to the northwest and NW-SE tension to the east [e.g., Montone et al., 2004].

[50] 3. The ongoing extension or transtension on the Tindari Fault System may be induced by the right-lateral slip along the Sisifo Fault, for which the Tindari Fault System would represent an extensional or transtensional, horsetail-type termination [e.g., Sylvester, 1988].

[51] The above models may be synthesized in a general one, in which the Tindari Fault System is an accommodation structure, whose ongoing, complex kinematics is the result from the interaction between a spatially heterogeneous tectonic regime and the presence of inherited faults (i.e., those forming the Tindari Fault System).

[52] Whereas the contractional belt in the southern Tyrrhenian Sea is widely accepted as being connected with the Africa-Eurasia convergence [e.g., Goes et al., 2004; Pondrelli et al., 2004], to date, the causes for the extensional tectonics in the southeastern Tyrrhenian Sea are still debated and ascribed to three alternative processes: (1) a new rifting process along the NNE-SSW trending margins of the western Calabria and northeastern Sicily [Tortorici et al., 1995a; Monaco et al., 1997]; (2) back-arc stretching [e.g., Neri et al., 2002]; and (3) a counterclockwise rotation of the Ionian block, this process resulting in normal faulting along the Tyrrhenian margin of Calabria and along the Ionian margin of Sicily [D'Agostino and Selvaggi, 2004; Goes et al., 2004]. Goes et al. [2004], in particular, included the Tindari Fault System in a transtensional, diffuse, transform boundary linking the active contractional belts in the Ionian and southern Tyrrhenian compartments [see also Govers and Wortel, 2005]. By the data presented in this paper, we cannot clearly discriminate among the models proposed for 
the extensional tectonics of the southeastern Tyrrhenian region; however, the back-arc extension model and the model for a transform boundary (i.e., more properly a transfer zone linking two destructive margins) across the northeastern Sicily may better fit some of the data presented in this paper. Fore instance, the location of the Tindari Fault System right above the western edge of the Ionian narrow slab, where a complex pattern of mantle return flow is expected [Gvirtzman and Nur, 1999; Marani and Trua, 2002; Faccenna et al., 2004, 2005], may well explain its ongoing transtensional kinematics by a combination of pure extension induced by the back-arc processes and of strikeslip movements induced by the mantle flows around the narrow slab [Funiciello et al., 2006]. Moreover, the ongoing transtensional displacements along the Tindari Fault System may support the model of a transfer zone across the northeastern Sicily; however, the evidence that the present activity of the Tindari Fault System is restricted to its northern portion suggests that if such transfer zone is truly developing, this should be in its inception stage. This hypothesis is consistent with the recent age (i.e., since $0.5-0.8 \mathrm{Ma}$ ) of inception of the transfer zone as proposed by Goes et al. [2004].

\section{Concluding Remarks}

[53] The geological and geophysical data presented in this paper allowed us to constrain the present-day pattern of the Tindari Fault System and to reconstruct its tectonic evolution since Neogene, with particular regard to the present seismotectonics. This latter, in turn, allowed us to make inferences about the present, regional, geodynamic setting, which, however, remains still unclear for the most part. Further surficial and deep data are necessary to better constrain the geometrical and tectonic characters of the crustal blocks occurring and interacting in this region. Among other feasible scientific schemes, a detailed fault mapping and a GPS monitoring over an appropriate network of measurement stations will be fundamental to improve our ability to decide between competing geodynamic and tectonic models. The knowledge of the appropriate geodynamic model will, in turn, contribute to define areas subject to significant tectonic stresses, thus providing the appropriate means to mitigate the natural hazards in such a densely populated region, which is at high risk for the frequent seismic and volcanic phenomena.

[54] Acknowledgments. This work was partly funded by a GNDT Project coordinated by L. Beranzoli with the help of P. Favali. We thank R. Funiciello for encouraging our work, F. Ghisetti for providing insightful references, C. Monaco for a fruitful discussion during a GNGTS meeting, F. Rossetti for a critical reading of a portion of the manuscript, F. Salvini for providing the DAISY 3 software for structural analyses, and G. Vignaroli for helping during fieldwork. Insightful comments by the Editor, the Associate Editor, and the reviewers significantly improved the paper.

\section{References}

Alvarez, W., T. Cocozza, and F. C. Wezel (1974), Fragmentation of the Alpine orogenic belt by microplate dispersal, Nature, 248, 309-314.

Amodio Morelli, L., et al. (1976), L'Arco CalabroPeloritano nell'orogene Appenninico-Maghrebide, Boll. Soc. Geol. Ital., 17, 1-60.

Anderson, H., and J. Jackson (1987), The deep seismicity of the Tyrrhenian Sea, Geophys. J. R. Astron. Soc., 91, 613-637.

Ansorge, J., D. Blundell, and S. Mueller (1992), Europe's lithosphere: Seismic structure, in A Continent Revealed: The European Geotraverse, edited by D. Blundell, R. Freeman, and S. Mueller, pp. $3-$ 70, Cambridge Univ. Press, New York.

Argnani, A., and C. Savelli (1999), Cenozoic volcanism and tectonics in the southern Tyrrhenian Sea: Space-time distribution and geodynamic significance, J. Geodyn., 27, 409-432.

Atzori, P., F. Ghisetti, A. Pezzino, and L. Vezzani (1978), Strutture ed evoluzione geodinamica recente dell'area Peloritana (Sicilia Nord-Orientale), Boll. Soc. Geol. Ital., 97, 31-56.

Barbagallo, F. (2003), Sicilia Nord-Est, Ist. Geogr. de Agostini, Novara, Italy.

Barbano, M. S., et al. (1978), Elementi per una carta sismotettonica della Sicilia e della Calabria meridionale, Mem. Soc. Geol. Ital., 19, 625-632.

Barberi, F., L. Civetta, P. Gasparini, F. Innocenti, R. Scandone, and L. Villari (1974), Evolution of a section of the Africa-Europe plate boundary: Paleomagnetic and vulcanological evidence from Sicily, Earth Planet. Sci. Lett., 22, 123-132.

Barone, A., A. Fabbri, S. Rossi, and R. Sartori (1982), Geological structure and evolution of the marine areas adjacent to the Calabrian arc, Earth Evol. Sci., 3, 207-221.
Beccaluva, L., G. Gabbianelli, F. Lucchini, P. L. Rossi, and C. Savelli (1985), Petrology and K/Ar ages of volcanic dredged from the Eolian seamounts: Implications for the geodynamic evolution of the southern Tyrrhenian basin, Earth Planet. Sci. Lett., 74, 187-208.

Bigi, G., D. Cosentino, M. Parotto, R. Sartori, and P. Scandone (Eds.) (1991), Structural Model of Italy, Soc. Elaborazioni Cartogr., Florence, Italy.

Boccaletti, M., and P. Manetti (1978), The Tyrrhenian Sea and adjoining regions, in The Ocean Basins and Margins, edited by A. E. M. Nairns, W. H. Knae, and F. G. Stehli, pp. 149-200, Springer, New York.

Bonardi, G., G. Giunta, B. Perrone, M. Russo, A. Zuppetta, and G. Ciampo (1980), Osservazioni sull'evoluzione dell'Arco Calabro Peloritano nel Miocene inferiore: La Formazione di Stilo Capo d'Orlando, Boll. Soc. Geol. Ital., 99, 365-393.

Bonardi, G., W. Cavazza, V. Perrone, and S. Rossi (2001), Calabria-Peloritani terrane and northern Ionian Sea, in Anatomy of an Orogen: The Apennines and Adjacent Mediterranean Basins, edited by G. B. Vai and I. P. Martini, pp. 287-306, Springer, New York.

Butler, R. W. H., M. Grasso, and F. La Manna (1992), Origin and deformation of the Neogene-Recent Maghrebian foredeep at the Gela Nappe, SE Sicily, J. Geol. Soc. London, 149, 547-556.

Caire, A. (1970), Sicily in its Mediterranean Setting, in Geology and History of Sicily, edited by W. Alvarez, and K. H. A. Gohrbandt, pp. 145-170, Pet. Explor. Soc. of Libya, Tripoli.

Catalano, S., and A. Cinque (1995), Dati preliminari sull'evoluzione neotettonica dei Peloritani settentrionali (Sicilia nord-orientale) sulla base dei dati morfologici, Studi Geol. Camerti, 1995(2), $113-$ 123.

Catalano, R., and B. D'Argenio (1978), An essay of palinspastic restoration across the western Sicily, Geol. Romana, 17, 145-159.

Catalano, S., and A. Di Stefano (1997), Sollevamenti e tettogenesi pleistocenica lungo il margine tirrenico dei Monti Peloritani: Integrazione dei dati geomorfologici, strutturali e biostratigrafici, Quaternario, 10, 337-342.

Catalano, R., P. Di Stefano, A. Sulli, and F. P. Vitale (1996), Paleogeography and structure of the central Mediterranean: Sicily and its offshore area, Tectonophysics, 260, 191-323.

Cifelli, F., F. Rossetti, M. Mattei, A. M. Hirt, R. Funiciello, and L. Tortorici (2004), An AMS, structural, and paleomagnetic study of quaternary deformation in eastern Sicily, J. Struct. Geol., 26, $29-46$.

D’Agostino, N., and G. Selvaggi (2004), Crustal motion along the Eurasia-Nubia plate boundary in the Calabrian Arc and Sicily and active extension in the Messina Straits from GPS measurements, J. Geophys. Res., 109, B 11402, doi:10.1029/ 2004JB002998.

D'Argenio, B., F. Horvath, and J. E. T. Channell (1980), Palaeotectonic evolution of Adria, the African Promontory, Mem. BRGM, 115, 331-351.

De Astis, G., G. Ventura, and G. Vilardo (2003), Geodynamic significance of the Aeolian volcanism (southern Tyrrhenian Sea, Italy) in light of structural, seismological, and geochemical data, Tectonics, 22(4), 1040, doi:10.1029/2003TC001506.

Dewey, J. F., M. L. Helman, E. Turco, D. H. W. Hutton, and D. Knott (1989), Kinematics of the western Mediterranean, in Alpine Tectonics, edited by M. P. 
Coward, D. Dietrich, and R. G. Park, Geol. Soc Spec. Publ., 45, 265-283.

Di Stefano, A., and R. Lentini (1995), Ricostruzione stratigrafica e significato paleotettonico dei depositi plio-pleistocenici del margine tirrenico tra Villafranca Tirrena e Faro (Sicilia nord-orientale), Studi Geol. Camerti, 1995(2), 219-237.

Evans, J. R., D. Eberhart-Phillips, and C. H. Thurber (1994), User's manual for SIMULPS12 for imaging $V_{P}$ and $V_{P} / V_{S}$ : A derivative of the "Thurber" tomographic inversion SIMUL3 for local earthquakes and explosions, U.S. Geol. Surv. Open File Rep., 94-431.

Fabbri, A., F. Ghisetti, and L. Vezzani (1980), The Peloritani-Calabria range and the Gioia Basin in the Calabrian Arc (southern Italy): Relationships between land and marine data, Geol. Romana, 19, $131-150$.

Fabbri, A., P. Gallignani, and N. Zitellini (1981), Geologic evolution of the Peri-Tyrrhenian sedimentary basins of Mediterranean margins, in Sedimentary Basins of Mediterranean Margins, edited by F. C. Wezel, pp. 101-126, Tecnoprint, Bologna, Italy.

Faccenna, C., C. Piromallo, A. Crespo-Blanc, and L. Jolivet (2004), Lateral slab deformation and the origin of the western Mediterranean arcs, Tectonics, 23, TC1012, doi:10.1029/2002TC001488.

Faccenna, C., L. Civetta, M. D'Antonio, F. Funiciello, L. Margheriti, and C. Piromallo (2005), Constraints on mantle circulation around the deforming Calabrian slab, Geophys. Res. Lett., 32, L06311, doi:10.1029/2004GL021874.

Finetti, I., and A. Del Ben (1986), Geophysical study of the Tyrrhenian opening, Boll. Geofis. Teor. Appl., 110, $75-156$.

Funiciello, F., M. Moroni, C. Piromallo, C. Faccenna, A. Cenedese, and H. A. Bui (2006), Mapping mantle flow during retreating subduction: Laboratory models analyzed by feature tracking, J. Geophys. Res., 111, B03402, doi:10.1029/2005JB003792.

Gasparini, P., G. Iannaccone, P. Scandone, and R. Scarpa (1982), Seismotectonics of the Calabrian arc, Tectonophysics, 84, 261-286.

Ghisetti, F. (1979), Relazioni tra strutture e fasi trascorrenti e distensive lungo i sistemi Messina-Fiumefreddo, Tindari-Letojanni e Alia-Malvagna (Sicilia nord-orientale): Uno studio microtettonico, Geol. Romana, 18, 23-58.

Ghisetti, F. (1992), Fault parameters in the Messina Strait (southern Italy) and relations with the seismogenic source, Tectonophysics, 210, 117-133.

Ghisetti, F., and L. Vezzani (1978), Dati preliminari sulla neotettonica dei Fogli 252 (Naso), 253 (Castroreale), 254 (Messina-Reggio C.), 261 (Bronte), e 262 (M. Etna), in Contributi Preliminari alla Realizzazione della Carta Neotettonica d'Italia, Publ. Progetto Finalizzato Geodin. 155, pp. 247-260, Cons. Naz. delle Ric., Rome.

Ghisetti, F., and L. Vezzani (1981), Contribution of structural analysis to understanding the geodynamic evolution of the Calabrian arc, J. Struct. Geol., 3, $371-381$.

Giardini, D., and M. Velonà (1988), La sismicità profonda del Mar Tirreno, Mem. Soc. Geol. Ital., 41, $1079-1087$.

Giunta, G., and F. Nigro (1999), Tectono-sedimentary constraints to the Oligocene-to-Miocene evolution of the Peloritani thrust belt (NE Sicily), Tectonophysics, 315, 287-299.

Goes, S., D. Giardini, S. Jenny, C. Hollenstein, H. G. Kahle, and A. Geiger (2004), A recent tectonic reorganization in the south-central Mediterranean, Earth Planet. Sci. Lett., 226, 335-345.

Govers, R., and M. J. R. Wortel (2005), Lithosphere tearing at STEP faults: Response to edges of subduction zones, Earth Planet. Sci. Lett., 236, $505-$ 523 .

Gvirtzman, Z., and A. Nur (1999), The formation of Mount Etna as the consequence of slab rollback, Nature, 401, 782-785.

Hollenstein, C., H. G. Kahle, A. Geiger, S. Jenny, S. Goes, and D. Giardini (2003), New GPS con- straints on the Africa-Eurasia plate boundary zone in southern Italy, Geophys. Res. Lett., 30(18), 1935, doi:10.1029/2003GL017554

Isacks, B., and P. Molnar (1971), Distribution of stresses in the descending lithosphere from a global survey of focal mechanism solutions of mantle earthquakes, Rev. Geophys., 9, 103-174.

Kastens, K., J. Mascle, and Shipboard Scientific Party (1988), ODP Leg 107 in the Tyrrhenian Sea: Insights into passive margin and back-arc basin evolution, Geol. Soc. Am. Bull., 100, 1140-1156.

Lanzafame, G., and J. C. Bousquet (1997), The Maltese escarpment and its extension from Mt. Etna to the Aeolian Islands (Sicily): Importance and evolution of a lithosphere discontinuity, Acta Vulcanol., 9, $113-120$.

Laubscher, H. P. (1988), The arcs of the western Alps and the northern Apennines: An updated view, $\mathrm{Tec}-$ tonophysics, 146, 67-78.

Lentini, F., S. Carbone, S. Catalano, A. Di Stefano, C. Gargano, M. Romeo, S. Strazzulla, and G. Vinci (1995), Sedimentary evolution of basins in mobile belts: Examples from Tertiary terrigenous sequences of the Peloritani Mts (NE Sicily), Terra Nova, 7 , $161-170$.

Lentini, F., M. Grasso, S. Carbone, and S. Catalano (1996), Elementi per la ricostruzione del quadro strutturale della Sicilia orientale, Mem. Soc. Geol. Ital., 51, 179-195.

Lentini, F., S. Catalano, and S. Carbone (2000), Carta geologica della Provincia di Messina, SELCA, Florence, Italy.

Lickorish, W. H., M. Grasso, R. W. H. Butler, A. Argnani, and R. Maniscalco (1999), Structural styles and regional tectonic setting of the "Gela Nappe" and frontal part of the Maghrebian thrust belt in Sicily, Tectonics, 18, 655-668.

Malinverno, A. (1981), Quantitative estimates of age and Messinian paleobathymetry of the Tyrrhenian Sea after seismic reflections heat flow and geophysical models, Boll. Geofis. Teor. Appl., 23, 159 171

Malinverno, A., and W. B. F. Ryan (1986), Extension in the Tyrrhenian Sea and shortening in the Apennines as result of arc migration driven by sinking of the lithosphere, Tectonics, 5, 227-254.

Marani, M. P., and T. Trua (2002), Thermal constriction and slab tearing at the origin of a superinflated spreading ridge: Marsili volcano (Tyrrhenian Sea) J. Geophys. Res., 107(B9), 2188, doi:10.1029/ 2001JB000285.

McKenzie, D. (1970), Plate tectonics of the Mediterranean region, Nature, 226, 239-243.

McKenzie, D. (1972), Active tectonics of the Mediterranean region, Geophys. J. R. Astron. Soc., 30, $109-185$.

Monaco, C., and L. Tortorici (2000), Active faulting in the Calabrian arc and eastern Sicily, J. Geodyn., 29, 407-424.

Monaco, C., P. Tapponier, L. Tortorici, and P. Y. Gillot (1997), Late Quaternary slip rates on the AcirealePiedimonte normal faults and tectonic origin of $\mathrm{Mt}$ Etna (Sicily), Earth Planet. Sci. Lett., 147, 125 139

Montelli, R., G. Nolet, F. A. Dahlen, G. Masters, E. R. Engdahl, and S.-H. Hung (2004), Finite-frequency tomography reveals a variety of plumes in the mantle, Science, 303, 338-343.

Montone, P., M. T. Mariucci, S. Pondrelli, and A. Amato (2004), An improved stress map for Italy and surrounding regions (central Mediterranean), J. Geophys. Res., 109, B10410, doi:10.1029/ 2003JB002703.

Nappi, G., V. Bonasia, M. Ferri, S. Montagna, and F. Pingue (1976), Primi risultati sulla sorveglianza del complesso vulcanico Lipari-Vulcano (Tirreno meridionale), Boll. Soc. Geol. Ital., 95, 967-980.

Neri, G., D. Caccamo, O. Cocina, and A. Montalto (1996), Geodynamic implications of earthquake data in the southern Tyrrhenian sea, Tectonophysics, $258,233-249$
Neri, G., G. Barberi, B. Orecchio, and M. Aloisi (2002), Seismotomography of the crust in the transition zone between the southern Tyrrhenian and Sicilian tectonic domains, Geophys. Res. Lett., 29(23), 2135, doi:10.1029/2002GL015562.

Neri, G., G. Barberi, B. Orecchio, and A. Mostaccio (2003), Seismic strain and seismogenic stress regimes in the crust of the southern Tyrrhenian region, Earth Planet. Sci. Lett., 213, 97-112.

Nicolich, R. (1989), Crustal structures from seismic studies in the frame of the European Geotraverse (southern segment) and CROP projects, in The Lithosphere in Italy, edited by A. Boriani et al., pp. $41-61$, Accad. Naz. dei Lincei, Rome.

Nigro, F. (1996), Late Oligocene-early Miocene sedimentary evolution of the foreland basins in the $\mathrm{Si}$ cilian mobile belt: The example of the Peloritani area, Terra Nova, 8, 611-625.

Ogniben, L. (1960), Nota illustrativa dello schema geologico della Sicilia nord-orientale, Riv. Miner. Siciliana, 64-65, 183-212.

Ollier, C. (1981), Tectonics and Landforms, 324 pp., Longman, New York.

Pasquale, V., M. Verdoya, P. Chiozzi, and G. Ranalli (1997), Rheology and seismotectonic regime in the northern central Mediterranean, Tectonophysics, 270, 239-257.

Patacca, E., R. Sartori, and P. Scandone (1990), Tyrrhenian basin and Apenninic arcs: Kinematic relations since late Tortonian times, Mem. Soc. Geol. Ital., 45, 425-451.

Peccerillo, A. (2003), Plio-Quaternary magmatism in Italy, Episodes, 26, 222-226.

Pepe, F. (1996), STM 96, un sistema finalizzato all'acquisizione multicanale ed all'elaborazione di segnali sismici ad alta risoluzione, paper presented at $15^{\circ}$ Convegno Gruppo Nazionale Geofisica della Terra Solida, Cons. Naz. delle Ric. Rome.

Pepe, F., G. Bertotti, F. Cella, and E. Marsella (2000), Rifted margin formation in the south Tyrrhenian Sea: High resolution seismic profile across the north Sicily passive continental margin, Tectonics, 19, 241-257.

Pepe, F., G. Bertotti, and S. Cloething (2004), Tectonostratigraphic modelling of the North Sicily continental margin (southern Tyrrhenian Sea), Tectonophysics, 384, 257-273.

Pepe, F., A. Sulli, G. Bertotti, and R. Catalano (2005), Structural highs formation and their relationship to sedimentary basins in the north Sicily continental margin (southern Tyrrhenian Sea): Implication for the Drepano Thrust Front, Tectonophysics, 409, 1 -

Piromallo, C., and A. Morelli (2003), P wave tomography of the mantle under the Alpine-Mediterranean area, J. Geophys. Res., 108(B2), 2065, doi:10.1029/ 2002JB001757.

Pondrelli, S., A. Morelli, and E. Boschi (1995), Seismic deformation in the Mediterranean area estimated by moment tensor summation, Geophys. J. Int., 122, $938-952$.

Pondrelli, S., C. Piromallo, and E. Serpelloni (2004), Convergence vs. retreat in southern Tyrrhenian Sea: Insights from kinematics, Geophys. Res. Lett., 31, L06611, doi:10.1029/2003GL019223.

Rehault, J. P., E. Moussat, and A. Fabbri (1987), Structural evolution of the Tyrrhenian back-arc basin, Mar. Geol., 74, 123-150.

Romano, R. (Ed.) (1983), Mount Etna Volcano, Mem. Soc. Geol. Ital., 23, 1-205.

Royden, L. H., and B. C. Burchfiel (1989), Are systematic variations in thrust belt style related to plate boundary processes? (The western Alps versus the Carpathians), Tectonics, 8, 51-62.

Ryan, W. B. F., et al. (1973), Initial Reports of the Deep Sea Drilling Project, vol. 13, pp. 403-464, U.S. Gov. Print. Off., Washington, D. C.

Salvini, F., and E. Vittori (1982), Analisi strutturale della linea Olevano-Antrodoco-Posta (AnconaAnzio Auct.): Metodologia di studio delle deformazioni fragili e presentazione del tratto 
meridionale, Mem. Soc. Geol. Ital., 24, 337356.

Sartori, R. (1990), The main results of ODP Leg 107 in the frame of Neogene to Recent evolution of the perityrrhenian area, Proc. Ocean Drill. Program Sci. Results, 107, 715-730.

Scarascia, S., A. Lozej, and R. Cassinis (1994), Crustal structures of the Ligurian, Tyrrhenian and Ionian Sea and adjacent onshore areas interpreted from wide-angle seismic profile, Boll. Geofis. Teor. Appl., 36, 5-19.

Sylvester, A. G. (1988), Strike-slip faults, Geol. Soc. Am. Bull., 100, 1666-1703.

Tortorici, L., C. Monaco, C. Tansi, and O. Cocina (1995a), Recent and active tectonics in the Calabrian arc (southern Italy), Tectonophysics, 243, $37-$ 55.

Tortorici, L., G. Ventura, R. Mazzuoli, and C. Monaco (1995b), Strutture del settore orientale dell'Arcipelago Eoliano: Interpretazione tettonica e modelliz- zazione numerica, Studi Geol. Camerti, 1995(2), $455-466$.

Valensise, G., and D. Pantosti (1992), A 125 Kyr-long geological record of seismic source repeatability: The Messina Straits (southern Italy) and the 1908 earthquake (MS 71/2), Terra Nova, 4, 472-483.

van Dijk, J., and M. Okkes (1991), Neogene tectonostratigraphy and kinematics of Calabrian basins: Implications for the geodynamics of the central Mediterranean, Tectonophysics, 196, 23-60.

Ventura, G., G. Vilardo, G. Milano, and N. A. Pino (1999), Relationships among crustal structure, volcanism and strike-slip tectonics in the Lipari-Vulcano Volcanic Complex (Aeolian Islands, southern Tyrrhenian Sea, Italy), Phys. Earth Planet. Inter. $116,31-52$.

Voltaggio, M., M. Barbieri, M. Branca, F. Castorina, A. Taddeucci, F. Tecce, P. Tuccimei, B. Turi, and P. Vesica (1997), Calcite in fractures in a volcanic environment (Vulcano Island, Italy): Contribution of geochronological and isotopic studies to volcanotectonics, J. Volcanol. Geotherm. Res., 75, $271-282$

G. Barberi, Istituto Nazionale di Geofisica Vulcanologia, Piazza Roma 2, I-95125, Catania, Italy. (barberi@ct.ingv.it)

A. Billi and C. Faccenna, Dipartimento di Scienze Geologiche, Università Roma Tre, Largo S. L. Murialdo, 1, I-00146, Rome, Italy. (billi@uniroma3.it; faccenna@ uniroma3.it)

G. Neri, Dipartimento di Scienze della Terra, Università di Messina, Salita Sperone 31, I-98166, Messina-Sant'Agata, Italy. (geoforum@unime.it)

F. Pepe and A. Sulli, Dipartimento di Geologia e Geodesia, Università di Palermo, Via Archirafi 26, I90123 , Palermo, Italy. (fapepe@unipa.it; attsu@unipa.it) 